\title{
Comparison of Thermal Degradation, WAXRD Studies and SEM of Renewable Resources Based Interpenetrating Polymer Networks
}

\author{
B. Satpathy ${ }^{1}$, N.C. Pal ${ }^{*}$ \\ ${ }^{1}$ Laboraratory of Polymers and Fibers, P.G. Department of Chemistry, Ravenshaw University, Cuttack, Odisha, \\ India \\ *Department of Chemistry, Shailabala Women's College, Cuttack, Odisha, India
}

\begin{abstract}
Recently bio-based polymers have received great importance due to their eco-friendly properties towards environment. As a substitute of conventional reinforcing synthetic polymer, bio-based polymers were from renewable resources like cardanol, i.e., the meta-substituted phenolic compound the chief product of CNSL. A number of IPNs have been synthesized by condensing di-azotised-4-amino benzoic acid and 3-amino benzoic acid cardanol dye with polyurethane of soybean oil. The IPNs produced have been characterized by FTIR, TGA, DSC (Differential scanning calorimetry). Elemental analysis and WAXRD studies. Thermal stability of IPNs has been studied by both TGA and DSC which provides heat capacity and kinetic parameters (order of reaction and activation energy) by Freeman Anderson method of the sample.
\end{abstract}

Keywords: Cardanol based dye, thermal stability, crystallinity, activation energy, interpenetrating polymer network.

\section{Introduction}

A survey of literature reveals that bio based polymer materials widely used in paints, varnishes, coatings, adhesives. These IPNs has been synthesized by diazotised cardanol with Pus of soybean oil. As both the starting materials of the new polymers are natural resources, hence polymer chemists have turned their attention to this synthesis. This paper aims to present a highly cross-linked polymer from agricultural products which have high temperature resistance. The structural confirmation of the polymer has been established by FTIR and WAXRD studies. Thermal resistance is studied by TGA and DSC.

\section{Experimental Section}

Materials:

- Refined soybean oil obtained from market.

- Cardanol was obtained from fractional distillation of CNSL liquid, a by-product of Sathya cashew chemical pvt. Ltd., Chennai.

- $\mathrm{NaOH}, \mathrm{MEK}, \mathrm{EGDM}, \mathrm{NaNO}_{2}, \mathrm{HCl}, \mathrm{PbO}$,etc. Were obtained from M/S BDH. Ltd. (INDIA)

- TDI, DPMDI, 3-amino benzoic acid and 4-amino benzoic acid from E-merk (GERMANY). All chemicals were used as received

\section{Methods:}

1. Spectroscopic Analysis- FTIR (Fourier transform infrared):FTIR spectra of the prepared IPNs samples have been recorded on FTIR Spectrophotometer by Thermo Electric Corporation, USA, and Model: Nicolet 670 FT-IR using KBr pallete in the wavelength range of $500 \mathrm{~cm}^{-1}$ to $4000 \mathrm{~cm}^{-1}$.

2. Thermal Analysis (DSC and TGA):DSC and TGA of all IPNs have been performed by use of a Universal $\mathrm{v}_{4} .5 \mathrm{~A} . \mathrm{TA}$ instrument (Model SDT Q $600 \mathrm{~V} 20.9$ Build 20) at a heating rate of $10^{\circ} \mathrm{c} /$ minute.

3. Morphology study (SEM): Morphology of samples has been studied by JOEL scanning electron microscope (SEM) Model JSM 500. For this the fractured samples have been coated with a thin layer of gold- platinum alloy by sputtering to provide conductive surface.

4. Element detection: IPNs are heated for 30 seconds in different scale count and the percentage of Carbon, Nitrogen and Oxygen atoms are given in the graphs.

5. Study of Crystallinity- Wide Angle X-ray diffraction study (WAXRD): X-ray diffraction pattern of polymer samples have been collected using a panalytical x'pert pro $\Theta / \Theta$ goniometer with $\mathrm{Cu}-\mathrm{K} \alpha$ radiation.

6. Test for biodegradability: The environmental resistance of the IPNs samples was carried out using soil burial test. 
Experimental:-

i. Preparation of dye monomer- $6.85 \mathrm{~g}$ of 4 - amino benzoic acid was dissolved in $25 \mathrm{ml}$ of conc. $\mathrm{HCl}$ acid and $25 \mathrm{ml}$ of water was added to it. The solution was cooled $0^{0}-5^{\circ} \mathrm{C}$, and then a cold solution of sodium nitrite (4g in $20 \mathrm{ml}$ of water) was added to it slowly with stirring for 3-4 minutes. A cold solution of cardanol (15g in $45 \mathrm{ml})$ of $10 \% \mathrm{NaOH}$ solution was prepared. Then cold diazonium solution was added slowly to the alkaline cardanol solution with stirring. A brown colour semi liquid dye was formed. The dye was separated by a separating funnel.

ii. Preparation of Mixed Ester Polyol (MEP) from Soybean Oil(SO):Refined soybean oil (350ml) was heated at $250^{\circ} \mathrm{C}$ in an inert Nitrogen atmosphere taken in three naked flask fitted with a thermometer reflux condensers and a stirrer. At this temperature litherage $(0.168 \mathrm{~g})$ and glycol $(80 \mathrm{ml})$ were added to the reaction mixture with constant stirring. The temperature was maintained at $210^{\circ} \mathrm{C}$ until one volume of reaction mixture gave a clear solution in same volume methanol. At this stage the contents were cooled to obtain MEP.

iii. Synthesis of Polyurethane (PU): 1 mole of MEP was added to 1.6 mole of TDI to maintain NCO/OH ratio at 1.6.The reaction was carried out at $75^{\circ} \mathrm{C}$ with continuous stirring for one hour until a viscous pale yellow colour PU is separated out. The same process was repeated with different $\mathrm{NCO} / \mathrm{OH}$ ratio $(1.2,1.6$, and 2.0) and with other diisocyanate DPMDI PUs was produced.

iv. Synthesis of IPNs: The mixture of PU and diazotised cardanol (with different PU/monomer ratio i.e., (75:25, 50:50, 65:35) and solvent (MEK) were taken in small beaker. Then 5ml of 10\% EGDM along with $20 \mathrm{mg}$ of Benzoyl peroxide (BPO) were added to each mixture. The total mixture was stirred for 15 minutes with magnetic stirrer in cold to obtain a homogenous solution. Then the temperature is raised to $75^{\circ} \mathrm{C}$ and stirred until a thick solution was formed. Then the viscous mass was poured into a petridish in hot condition and kept in an oven at $75^{\circ} \mathrm{C}$ for 24 hour. The feed composition data of the different IPNs are given in table-

The thin film thus obtained was cooled and removed from the petridish with a sharp blade and sent for characterisation to the Central Instrumentation Facility Pondicherry University, Puducherry, pin- 605014.

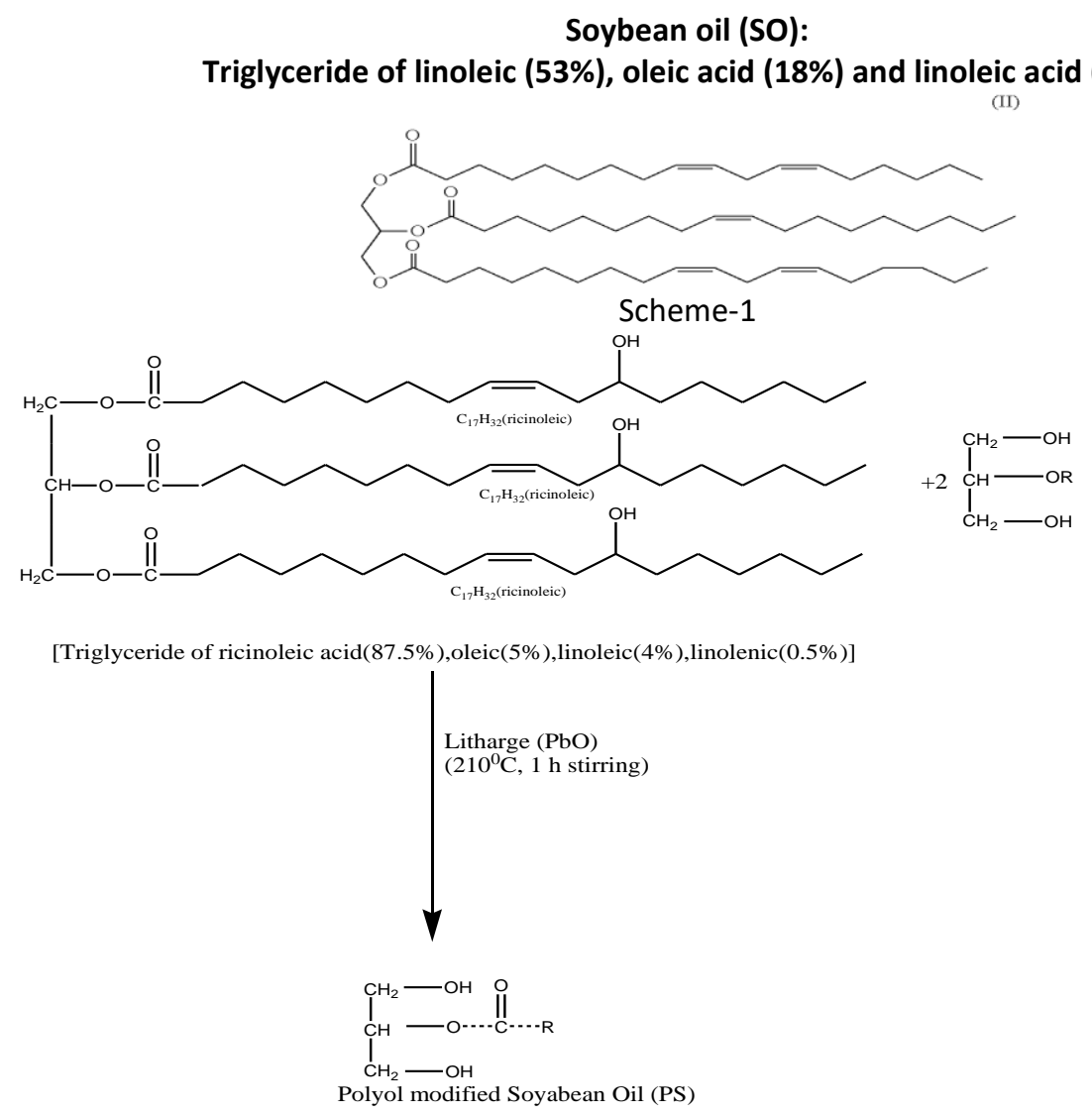




\section{Scheme - 2}

(1)<smiles>Nc1ccc(C(=O)O)cc1</smiles>

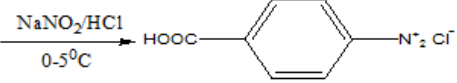

4-amino benzoic acid

[Diazonium salt]

(ii)

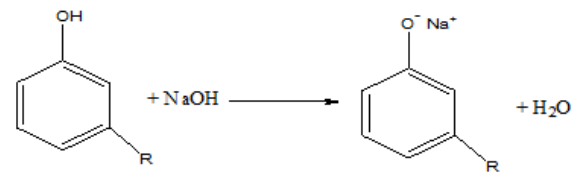

(iii)
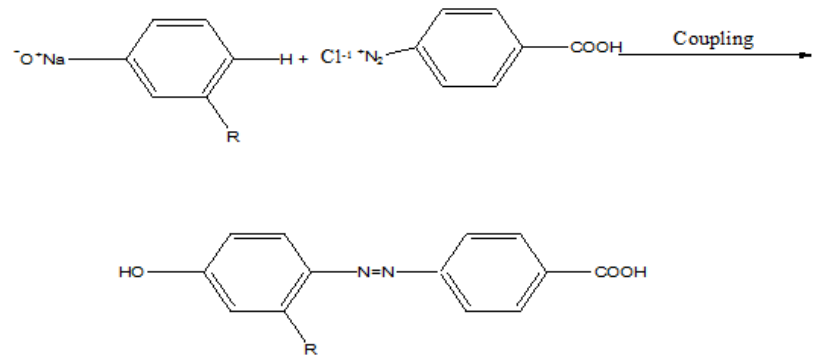

Cardanol based Dye (CD) with 4-aminobenzoic acid

Scheme -3

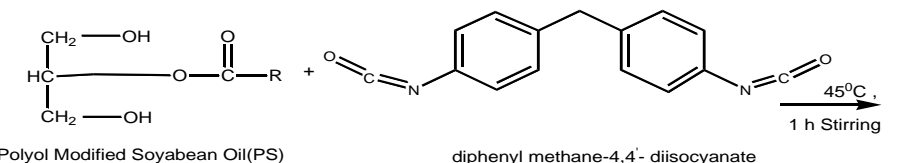
(DPMDI)<smiles>CCCC(=O)OC(COC)COC(=O)Nc1ccc(Cc2ccc(NC(=O)OCC(COC)OC(=O)P)cc2)cc1</smiles>

\section{(POLYURATHANE (PU))}

Scheme -4

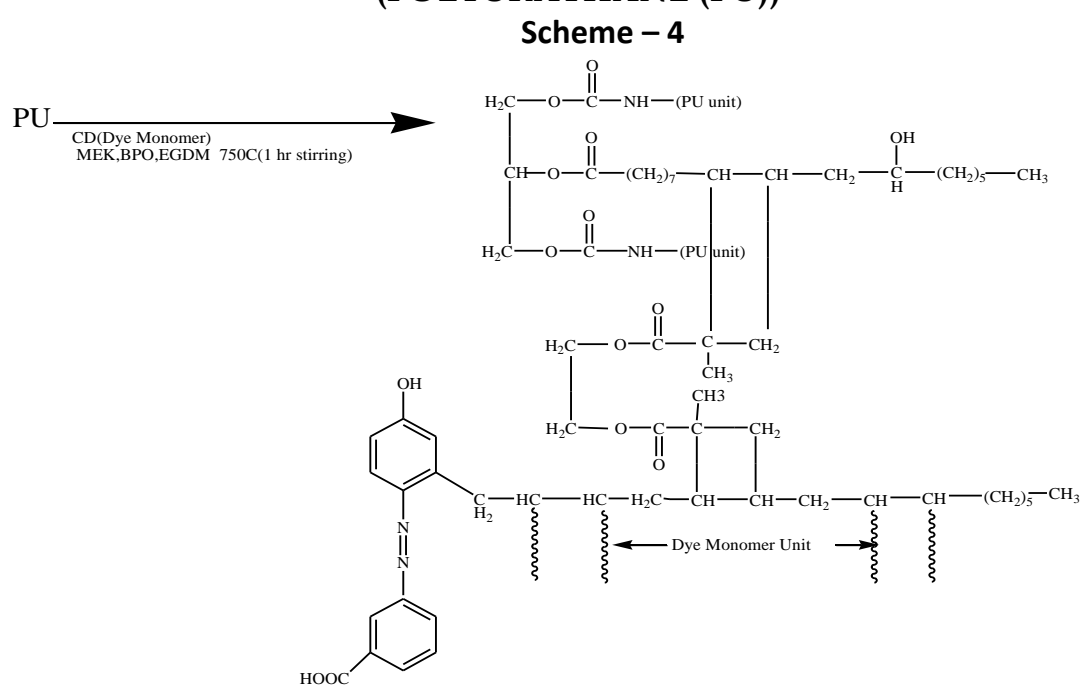

(INTERPENETRATING POLYMER NETWORK FROM NATURAL RESOURCES) 
Analysis of the Sample:

The FTIR spectra of the IPNs are presented in figs 1-a to 1-d

\section{FTIR OF IPN 27}

The characteristic absorption of IPN-27 corresponding to $\mathrm{O}-\mathrm{H}$ stretching of $>\mathrm{OH}$ groups shifted to lower value by hydrogen bonding at $3858.6 \mathrm{~cm}^{-1}$. N-H stretching of $>\mathrm{NH}$ group at $3444.5 \mathrm{~cm}^{-1}, \mathrm{C}-\mathrm{H}$ stretching (ss/as) of $>\mathrm{CH}_{2}$ and $>\mathrm{CH}_{3}$ groups at $2861.9 \mathrm{~cm}^{-1}$ and $2747.9 \mathrm{~cm}^{-1}, \mathrm{~N} \equiv \mathrm{C}$ stretching of $-\mathrm{N}=\mathrm{C}=\mathrm{O}$ group for the isocyanate terminating $\mathrm{PU}$ unit at $2319.9 \mathrm{~cm}^{-1}, \mathrm{C}=\mathrm{O}$ stretching of urethane linkage at $1660.3 \mathrm{bcm}{ }^{-1}, \mathrm{~N}=\mathrm{N}$ stretching of azo group at $1547.6 \mathrm{~cm}^{-1}, \mathrm{C}-\mathrm{O}$ bending at $1029.3 \mathrm{~cm}^{-1}, \mathrm{C}-\mathrm{C}$ stretching of aromatic rings at 1398.8 $\mathrm{cm}^{-1}$, out of plane C-H bending at $806.6 \mathrm{~cm}^{-1}$ and out of plane C-C bending at $691.8 \mathrm{~cm}^{-1}$ and $551.6 \mathrm{~cm}^{-1} \backslash$ were observed.

\section{FTIR OF IPN 32}

The characteristic absorption of IPN-32 corresponding to $-\mathrm{OH}$ stretching of $>\mathrm{OH}$ groups shifted to lower value by hydrogen bonding at $3446.3 \mathrm{~cm}^{-1}$. The $\mathrm{C}-\mathrm{H}$ stretching (ss/as) of $>\mathrm{CH}_{2}$ and $>\mathrm{CH}_{3}$ groups at $2797.6 \mathrm{~cm}^{-1}$ and $2921.6 \mathrm{~cm}^{-1}$,- $\mathrm{N} \equiv \mathrm{C}$ stretching of $-\mathrm{N}=\mathrm{C}=\mathrm{O}$ group for the isocyanate terminating PU unit at $2364.4 \mathrm{~cm}^{-1}, \mathrm{C}=\mathrm{O}$ stretching of urethane linkage at $1720.4 \mathrm{~cm}^{-1}$ and $1661.0 \mathrm{~cm}^{-1},-\mathrm{N}=\mathrm{N}$ stretching of azo group at $1581.2 \mathrm{~cm}^{-1},-\mathrm{N}=\mathrm{N}$ stretching of aromatic rings at $1581.2 \mathrm{~cm}^{-1}, \mathrm{C}-\mathrm{O}$ bending at $1161.8 \mathrm{~cm}^{-1}, \mathrm{C}-\mathrm{C}$ stretching of aromatic rings at $1259.2 \mathrm{~cm}^{-1}, \mathrm{C}=\mathrm{C}$ stretching of aromatic rings at $1392.6 \mathrm{~cm}^{-1}, \mathrm{C}-\mathrm{O}$ stretching of ester at $1161.8 \mathrm{~cm}^{-1}$, out of plane C-H bending at $703.5 \mathrm{~cm}^{-1}$ and out of plane $\mathrm{C}-\mathrm{C}$ bending at $516.4 \mathrm{~cm}^{-1}$ were observed.

\section{FTIR OF IPN 35}

The characteristic absorption of IPN-35 corresponding to $-\mathrm{OH}$ stretching of $>\mathrm{OH}$ groups shifted to lower value by hydrogen bonding at $3606.2 \mathrm{~cm}^{-1}$. N-H stretching of $>\mathrm{NH}$ group at $3470.4 \mathrm{~cm}^{-1}, \mathrm{C}-\mathrm{H}$ stretching (ss/as) of $>\mathrm{CH}_{2}$ and $>\mathrm{CH}_{3}$ groups at $2921.0 \mathrm{~cm}^{-1}$ and $2861.0 \mathrm{~cm}^{-1}$,- $\mathrm{N} \equiv \mathrm{C}$ stretching of $-\mathrm{N}=\mathrm{C}=\mathrm{O}$ group for the isocyanate terminating $\mathrm{PU}$ unit at $2773.8 \mathrm{~cm}^{-1}$ and $2322.6 \mathrm{~cm}^{-1}, \mathrm{C}=\mathrm{O}$ stretching of urethane linkage at 1661.4 $\mathrm{cm}^{-1}, \mathrm{C}-\mathrm{O}$ bending at $1164.2 \mathrm{~cm}^{-1}, \mathrm{C}=\mathrm{C}$ stretching at $1540.2 \mathrm{~cm}^{-1}, \mathrm{C}=\mathrm{C}$ stretching of aromatic rings at 1540.2 $\mathrm{cm}^{-1}, \mathrm{C}-\mathrm{O}$ stretching of ester at $1161.0 \mathrm{~cm}^{-1}$, $-\mathrm{OH}$ bending of $-\mathrm{COOH}$ group at $1310.3 \mathrm{~cm}^{-1}$, out of plane $\mathrm{C}-\mathrm{H}$ bending at $869.6 \mathrm{~cm}^{-1}$ and out of plane $\mathrm{C}-\mathrm{C}$ bending at $713.8 \mathrm{~cm}^{-1}$ were observed.

\section{FTIR OF IPN 36}

The characteristic absorption of IPN-36 corresponding to $-\mathrm{OH}$ stretching of $>\mathrm{OH}$ groups shifted to lower value by hydrogen bonding at $3855.4 \mathrm{~cm}^{-1}$ and $3734.8 \mathrm{~cm}^{-1}$. N-H stretching of $>\mathrm{NH}$ group at $3395.3 \mathrm{~cm}^{-1}$, $\mathrm{C}-\mathrm{H}$ stretching (ss/as) of $>\mathrm{CH}_{2}$ and $>\mathrm{CH}_{3}$ groups at $2920.4 \mathrm{~cm}^{-1}$ and $2859.7 \mathrm{~cm}^{-1},-\mathrm{N} \equiv \mathrm{C}$ stretching of $-\mathrm{N}=\mathrm{C}=\mathrm{O}$ group for the isocyanate terminating PU unit at $2773.1 \mathrm{~cm}^{-1}, 2545.7 \mathrm{~cm}^{-1}$, and $2362.8 \mathrm{~cm}^{-1}, \mathrm{C}=\mathrm{O}$ stretching of urethane linkage at $1727.6 \mathrm{~cm}^{-1},-\mathrm{N}=\mathrm{N}$ stretching of azo group at $1579.3 \mathrm{~cm}^{-1}, \mathrm{C}-\mathrm{C}$ stretching of aromatic rings at $1404.7 \mathrm{~cm}^{-1}, \mathrm{C}=\mathrm{C}$ stretching of aromatic rings at $1530.7 \mathrm{~cm}^{-1}, \mathrm{C}-\mathrm{O}$ stretching of ester at $1161.9 \mathrm{~cm}^{-1},-\mathrm{OH}$ bending of $-\mathrm{COOH}$ group at $1306.3 \mathrm{~cm}^{-1}$, out of plane $\mathrm{C}-\mathrm{H}$ bending at $811.5 \mathrm{~cm}^{-1}$ and out of plane $\mathrm{C}-\mathrm{C}$ bending of p-substituted benzene rings at $644 \mathrm{~cm}^{-1}$ and $483 \mathrm{~cm}^{-1}$ were observed.

\section{CONCLUSION}

From the fig.1a to $1 \mathrm{~d}$ correlation with the peak of the authentic compound helps to identify the polymer sample. The $-\mathrm{OH}$ stretching shifted to lower value by hydrogen bond at 3607 and $3897 \mathrm{~cm}^{-1}$. The $\mathrm{N}-\mathrm{H}$ stretching of $>\mathrm{NH}_{2}$ group at $3333.5 \mathrm{~cm}^{-1}, \mathrm{C}-\mathrm{H}$ stretching (ss/as) of $>\mathrm{CH}_{2}$ and $>\mathrm{CH}_{3}$ groups at $2926.4 \mathrm{~cm}^{-1}$ and $2857.7 \mathrm{~cm}^{-}$ ${ }^{1},-\mathrm{N} \equiv \mathrm{C}$ stretching of $-\mathrm{N}=\mathrm{C}=\mathrm{O}$ group for the isocyanate terminating $\mathrm{PU}$ unit at $2341 \mathrm{~cm}^{-1}, \mathrm{C}=\mathrm{O}$ stretching of urethane linkage at $1660-1728 \mathrm{~cm}^{-1},-\mathrm{N}=\mathrm{N}$ stretching of azo group at $1590 \mathrm{~cm}^{-1}$ to $1620 \mathrm{~cm}^{-1}, \mathrm{C}-\mathrm{C}$ stretching of aromatic rings at $1399 \mathrm{~cm}^{-1}, \mathrm{C}=\mathrm{C}$ stretching of aromatic rings at $1518 \mathrm{~cm}^{-1},-\mathrm{OH}$ bending of $-\mathrm{COOH}$ group at $1120-1240 \mathrm{~cm}^{-1}$, out of plane C-H bending at $784 \mathrm{~cm}^{-1}$ and out of plane C-C bending of p-substituted benzene rings at $863.1 \mathrm{~cm}^{-1}$.

\section{D.Sc. (Differential Scanning Calorimetric Analysis):}

This method is used to characterize thermo physical properties of a polymer sample like melting point, heat of melting, percentage of crystallinity, $\mathrm{T}_{\mathrm{g}}$ or softening of the polymer. This method also helps us to observe phase transition.

Heat capacity $\mathrm{C}_{\mathrm{p}}=(\mathrm{Q} / \mathrm{m}) \Delta \mathrm{T}$

- Q: Heat added

- m:mass of material

- $\Delta \mathrm{T}=(\mathrm{Ts}-\mathrm{Tr})=$ Change in temperature 
$\Delta \mathrm{T}$ is zero for no reaction

Heat of fusion $=\mathrm{Q} / \mathrm{m}$

$$
\begin{aligned}
& \mathrm{C}_{\mathrm{p}}=\frac{d}{d T / d t} \times \frac{1}{m} \\
& \text { Percentage of crystallinity }=\frac{\Delta H m-\Delta H c}{\Delta H m} \times 100
\end{aligned}
$$

\section{Conclusion}

From the table-2 it is evident that IPN ${ }_{27}, \mathrm{IPN}_{35}, \mathrm{IPN}_{36}$ are more thermally stable than $\mathrm{IPN}_{32}$ which has Tm value 420.6 and lowest molar ratio. While other three IPNs are comparatively more thermally stable.IPN $\mathrm{P}_{32}$ has more Tg value than $\mathrm{IPN}_{27}, \mathrm{IPN}_{35}, \mathrm{IPN}_{36}$ due to lower PU content and $\mathrm{NCO} / \mathrm{OH}$ ratio (1.6).

\section{Thermogravimetric analysis}

Thermogravimetric analysis of IPNs was carried out as a function of weight loss verses temperature. Thermo grams are interpreted and analysed to obtain information about the percentage of weight loss at different temperatures from which kinetic parameters has been calculated in

Table-3a following Freeman-Anderson method and are shown in graphs named Fig 3a to $3 \mathrm{~h}$

\section{Conclusion:}

$\mathrm{IPN}_{32}$ is less stable at higher temperature than $\mathrm{IPN}_{27}, \mathrm{IPN}_{35}, \mathrm{IPN}_{36}$. All the three IPNs are stable upto700 ${ }^{0} \mathrm{C}$ polymer chain breaks nearly about $400^{\circ} \mathrm{C}$ to $450^{\circ} \mathrm{C}$.

$\mathrm{IPN}_{27}, \mathrm{IPN}_{35}, \mathrm{IPN}_{36}$ all have same NCO/OH molar ratio (i.e.2.0) are more stable than $\mathrm{IPN}_{32}$ lower NCO/OH ratio (1.6).

Kinetic parameters of IPNs by Freeman-Anderson method have been calculated as per the following equation and are shown in table $3 b$.

$\Delta \log \left(-\frac{d w}{d t}\right)=n \Delta \log w-\frac{E a}{2.303 R} \Delta\left(\frac{1}{T}\right)$

Where $\mathrm{n}=$ order of reaction

$\mathrm{E}_{\mathrm{a}}=$ Activation Energy

These values are determined from the plot of $\Delta \log \left(-\frac{d w}{d t}\right)$ vs $\Delta \log w$. The slope gives us order of reaction $\mathrm{n}$ and intercept is related to activation energy (Ea) which is given by Ea which is given by

\section{Element detection:}

$$
E a=\frac{- \text { Intercept } X 2.303 R}{\Delta\left(\frac{1}{T}\right)}
$$

IPNs are heated for 30 seconds in different scale count and the percentages of Carbon, Nitrogen and Oxygen atoms were found which are given in graphs named as Fig $5 \mathrm{a}, 5 \mathrm{~b}, 5 \mathrm{c}, 5 \mathrm{~d}$ and table- $4 \mathrm{a}$ to $4 \mathrm{k}$ respectively.

\section{Wide angle $X$ ray diffraction (WAXRD)}

This is a very good technique to analyse a polymer sample to know the percent of crystallinity. It is a non destructive method of characterisation of solid polymers. The samples have been scanned in a wide angle $\mathrm{X}$ ray goniometer and the scattering intensity is plotted as a function of $2 \Theta$ angle $\left(2 \Theta\right.$ is larger than $\left.5^{0}\right)$ as shown in fig$4 a, 4 b, 4 c, 4 d$ and table-5a,5b,5c,5d respectively.

\section{Conclusion}

From the above fact it is clear that IPN 27 is more crystalline than $\operatorname{IPN}_{32}, \mathrm{IPN}_{35}, \mathrm{IPN}_{36}$ all the IPNs prepared is a mixture of amorphous and crystalline substance are known as polymer blend. Each sample has a unique pattern of dspacing which is the figure print of that sample. The percentage of crystallinity increases with more PU content and decreases with more dye.

\section{SEM (scanning electron microscope) Study}

This technique has been used to study the morphology of polymer blends or samples. Morphology of polymer blends or samples consists of two distinct phases which was very clear in photos(fig- Fig 6a to 6h). Interpenetration of two phases i.e. crystalline and amorphous are also clearly seen in the photos named as Fig 6a to $6 \mathrm{~h}$ respectively.

\section{CONCLUSION}

IPN - 32 and IPN-35 exhibited greater degree of interpenetration, phase mixing and good morphology as compared to IPN-36 and IPN-27.This morphology is expected due to the ratio of PU and CD. This study shows complex phase behaviour of IPNs. Increase in PU content the heterogeneity increases and morphology changes from continuous to discontinuous phase. 


\section{BIODEGRADABILITY:}

The IPN samples synthesized were tested for environmental resistance by use of soil burial test. The samples were buried in soil for sixty days. The samples were removed from the soil once in fifteen days to access the changes in their weight loss, mechanical strength and surface damage if any.

\section{Conclusion}

From this observation(table-6) it is seen that these samples are not biodegradable, only a small amount of it decomposes with the bacteria and virus present in the soil which is very negligible.

\section{Acknowledgement}

The authors are thankful to the Registrar, Ravenshaw University, Odisha for his kind permission to provide the laboratory facility and help publish this paper. The authors are thankful to the Registrar, Utkal University, Bhubaneswar to publish the paper. The authors are also thankful to the Dean, Pondicherry University, Puduchery for characterisation of samples.

\section{References}

[1] Sperling L.H (1981) IPN related material plenum press New York.

[2] Yeo Jk, Sperling L.H, Thomas DA (1982) PolymEng Sc.(190)

[3] Yeo Jk, Sperling L.H, Thomas DA (1982) Polym 24 (307)

[4] Sperling L.H, Walsh DJ, Higgins JS,(1985) Macronnachie A (eds), polymer blend and mixture MartiniusNijhoff Dordrecht.

[5] Pillai CKS, Rohtagi PK, Gopa K, J Sic Ind Res 40, 1981

[6] Das D, Nayak SS, Das SK, Nayak PL, Lenka S, ThermochemActa (1997,297(101-107

[7] Achary P.G.R, Biswal s.,MahaptraS,.Pal N .C , Polymer Plastic tech. and Eng v-49 Issue 11 (2010)(p-1114-1120)

[8] Biswal S, Satpathy J .R. ,Achary P .G .R.,Pal N .C. Springer sc and B. M.(2012)

[9] Gopalkrishnanetal. Arch.Appl. SCi. Res. 20124 (2)1091-1099

[10] Biswal S, ,Achary P .G.R, MohantyN,.Pal N .C , Central institute of Plastic Engg\& Tech(2011)

[11] Panda M, Parida S, SamalSK,Das SC, Spectral and thermal study of Aloevera, J of Polymer Material Vol 26, No.-3, 2009

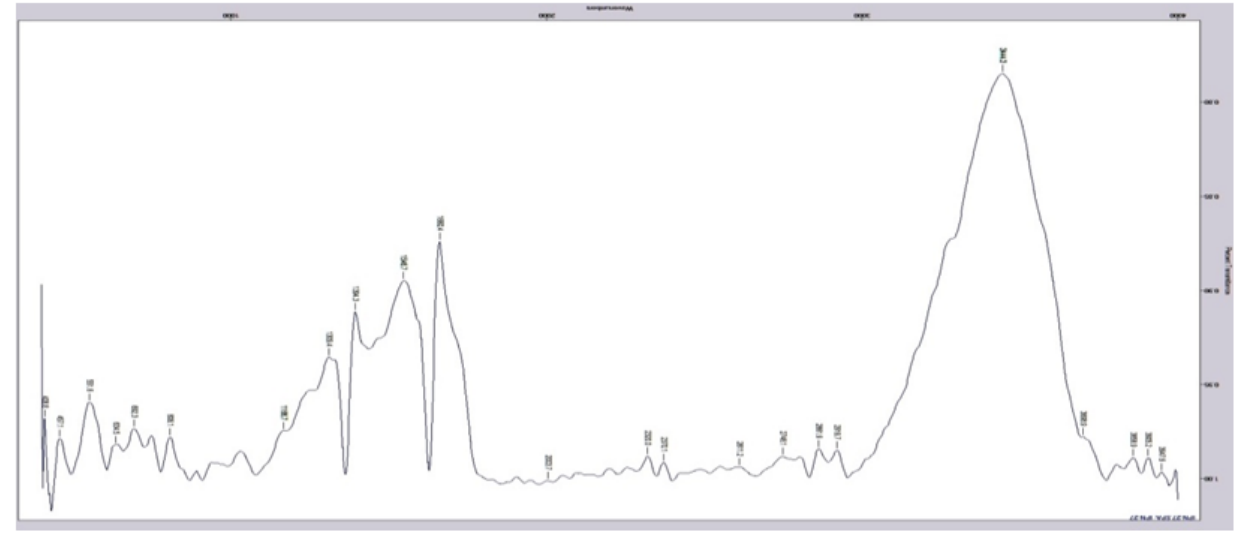

Fig 1a: FTIR OF IPN 27

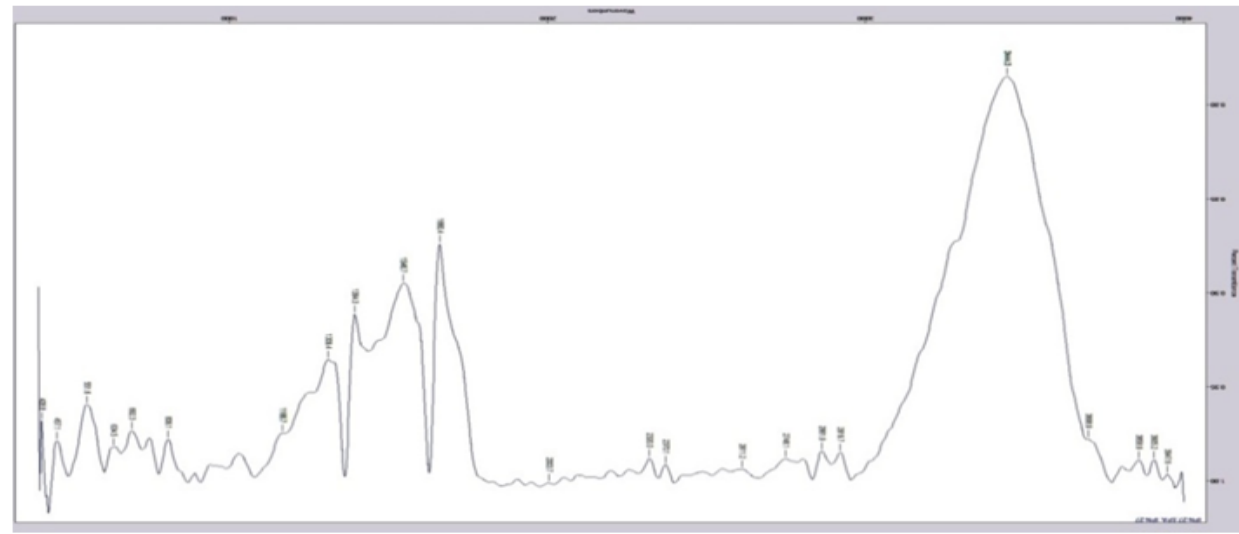

Fig 1b: FTIR OF IPN 32 


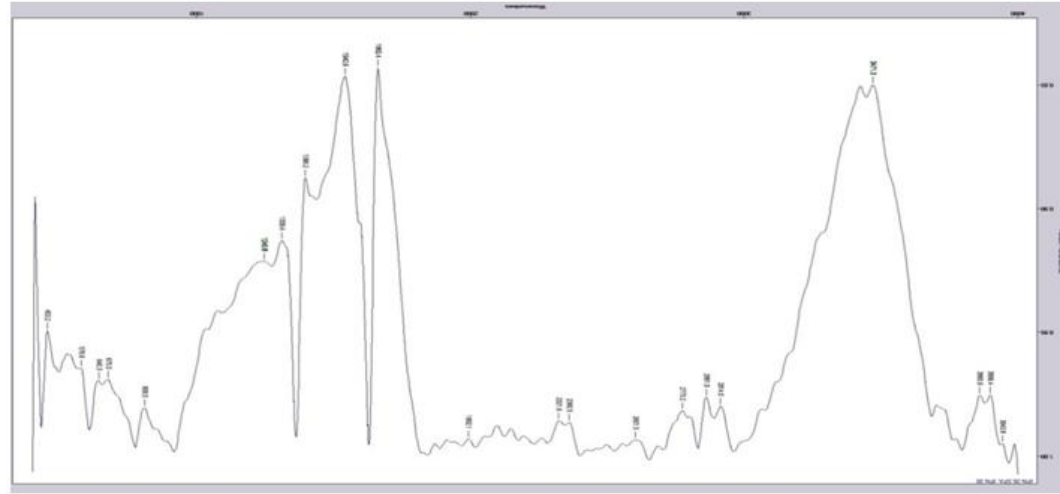

Fig 1c: FTIR OF IPN 35

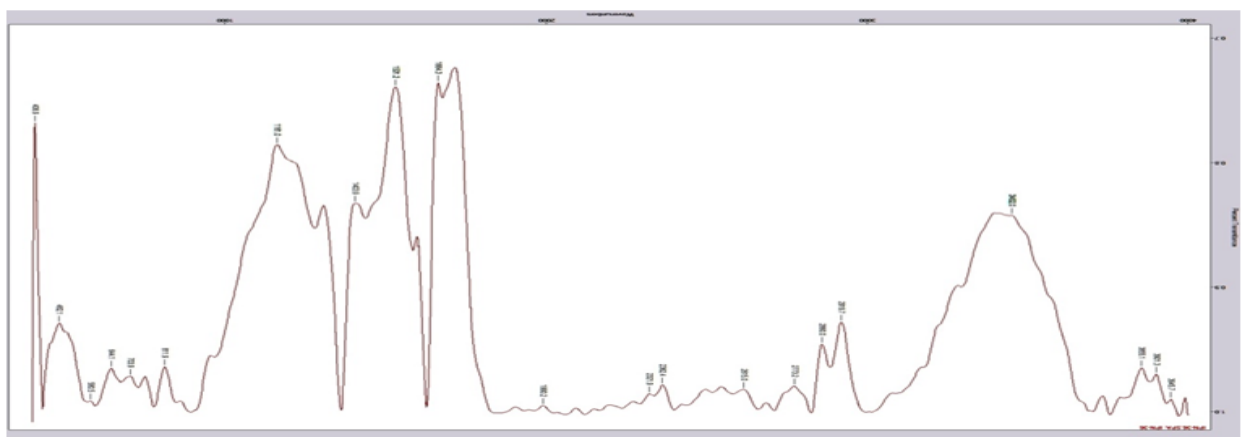

Fig 1d:FTIR OF IPN 36

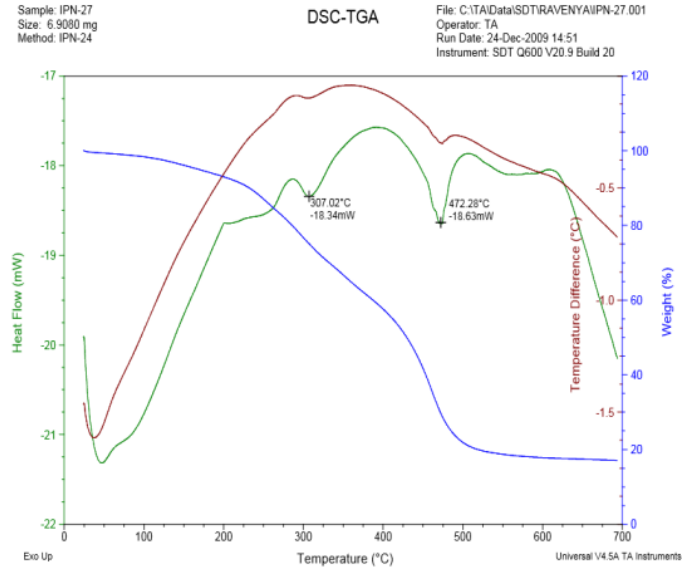

Fig 2a - DSC TGA OF IPN 27

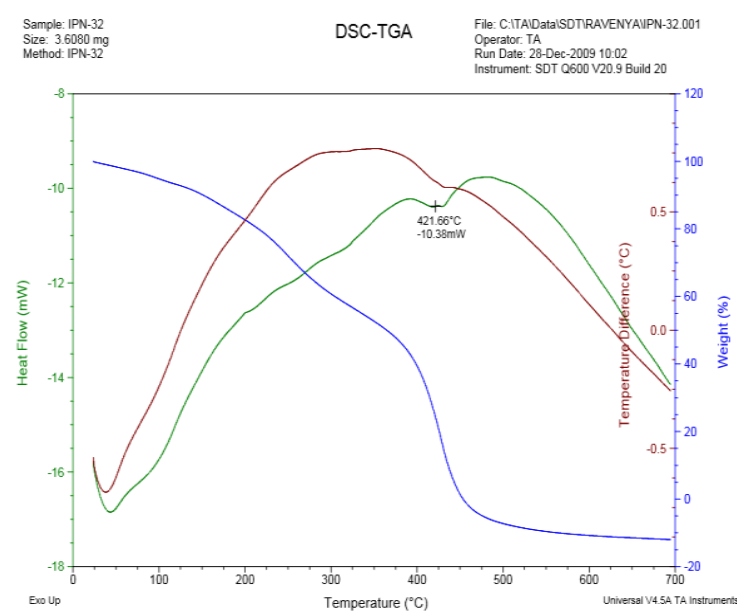

Fig $2 b$ - DSC TGA OF IPN 32 


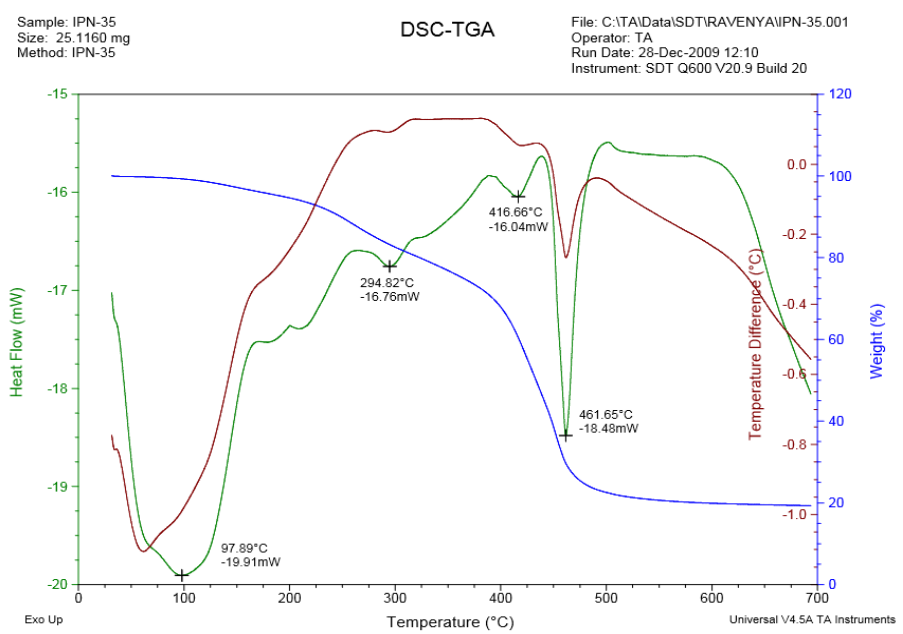

Fig 2c - DSC OF IPN 35

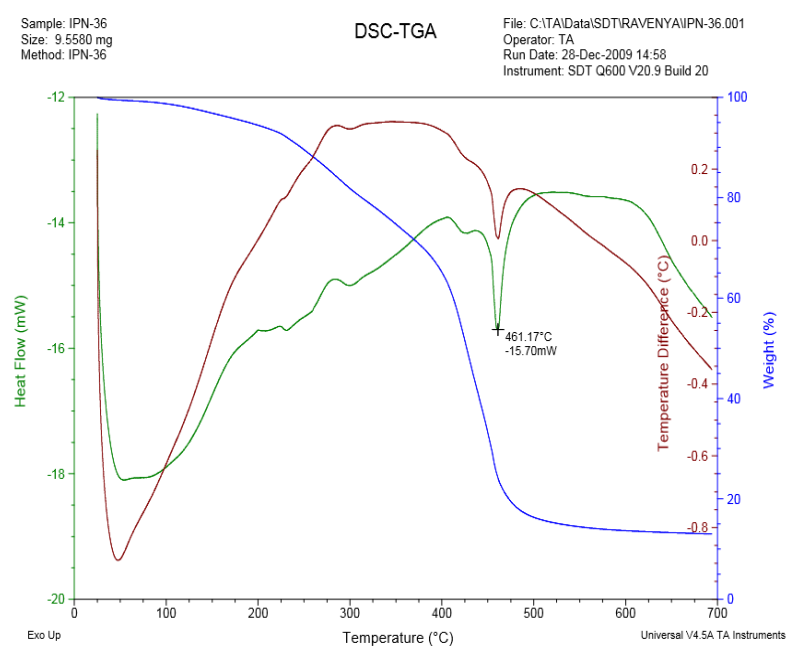

Fig 2d - DSC OF IPN 36

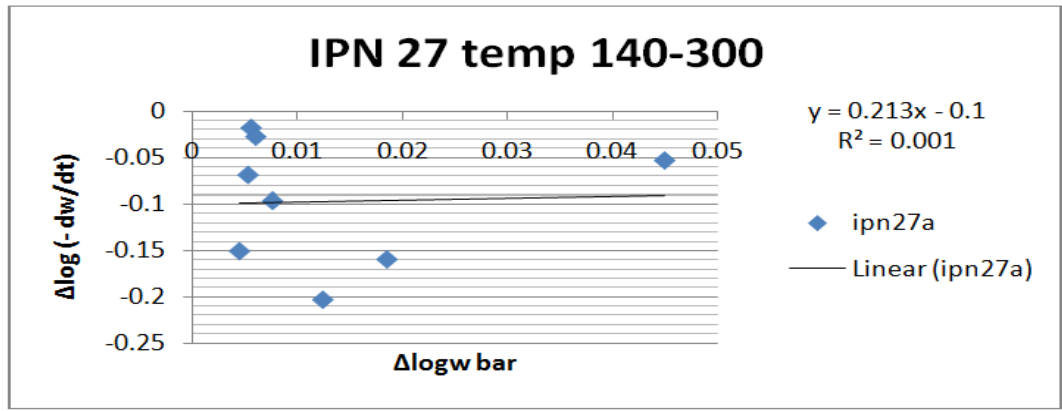

Fig 3a-Freeman-Anderson Plot of IPN27

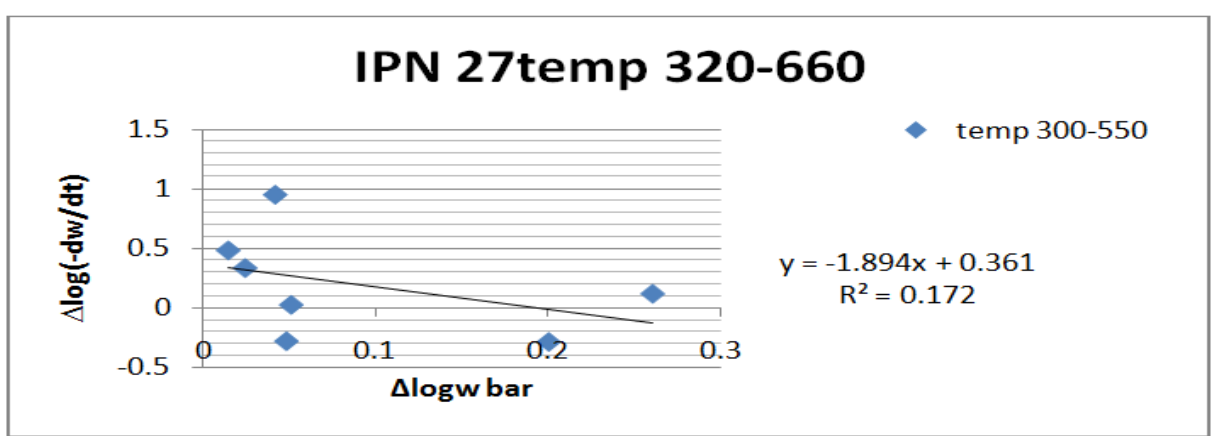

Fig 3b-Freeman-Anderson Plot of IPN27 


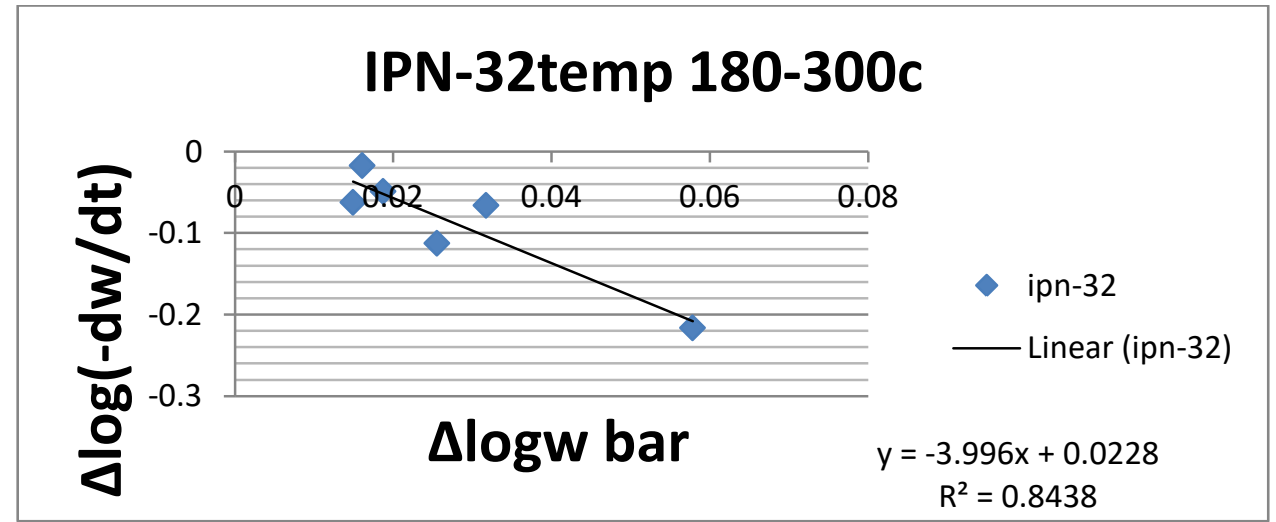

Fig 3c-Freeman-Anderson Plot of IPN32

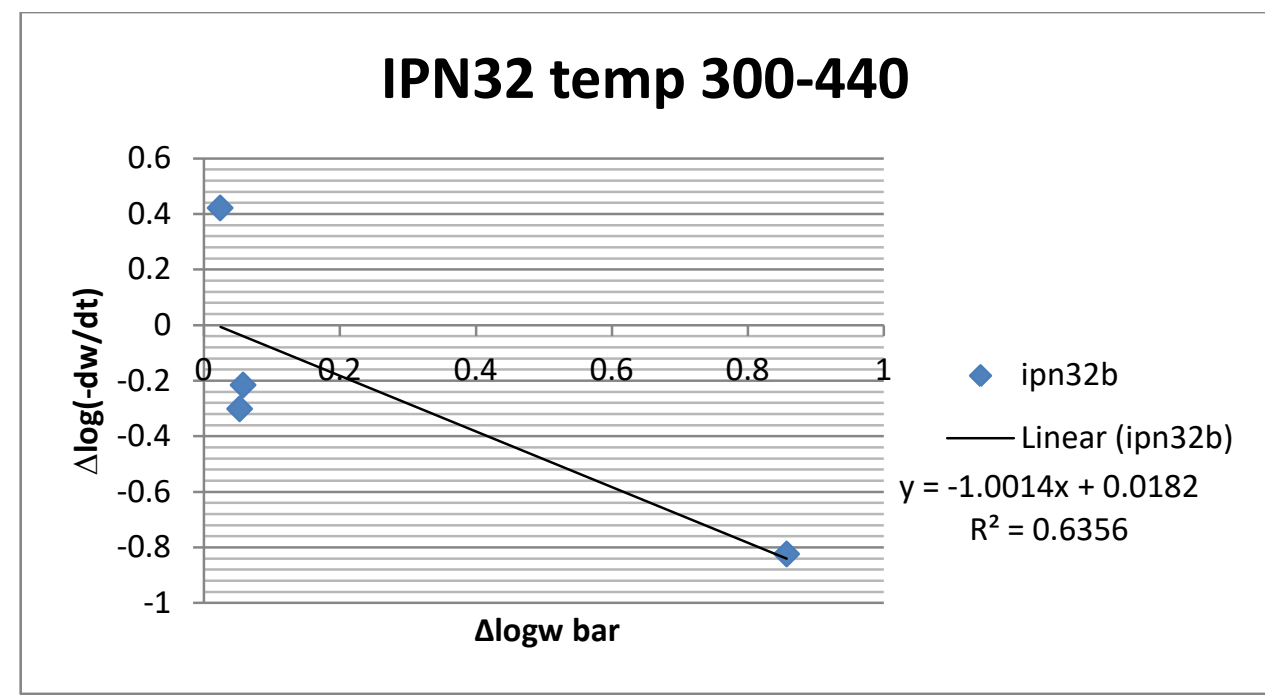

Fig 3d -Freeman-Anderson Plot of IPN32

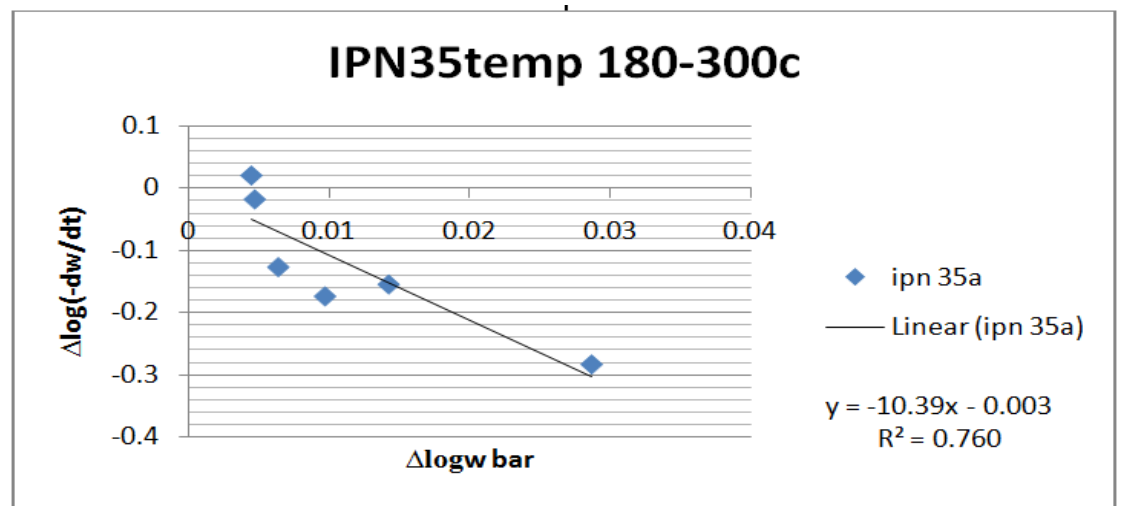

Fig 3e-Freeman-Anderson Plot of IPN35

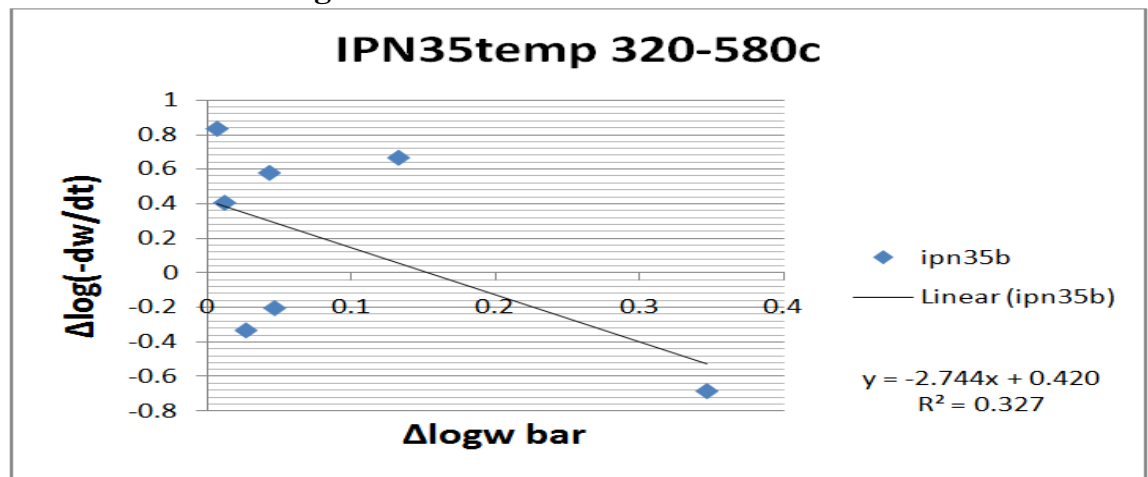

Fig 3f-Freeman-Anderson Plot of IPN35 


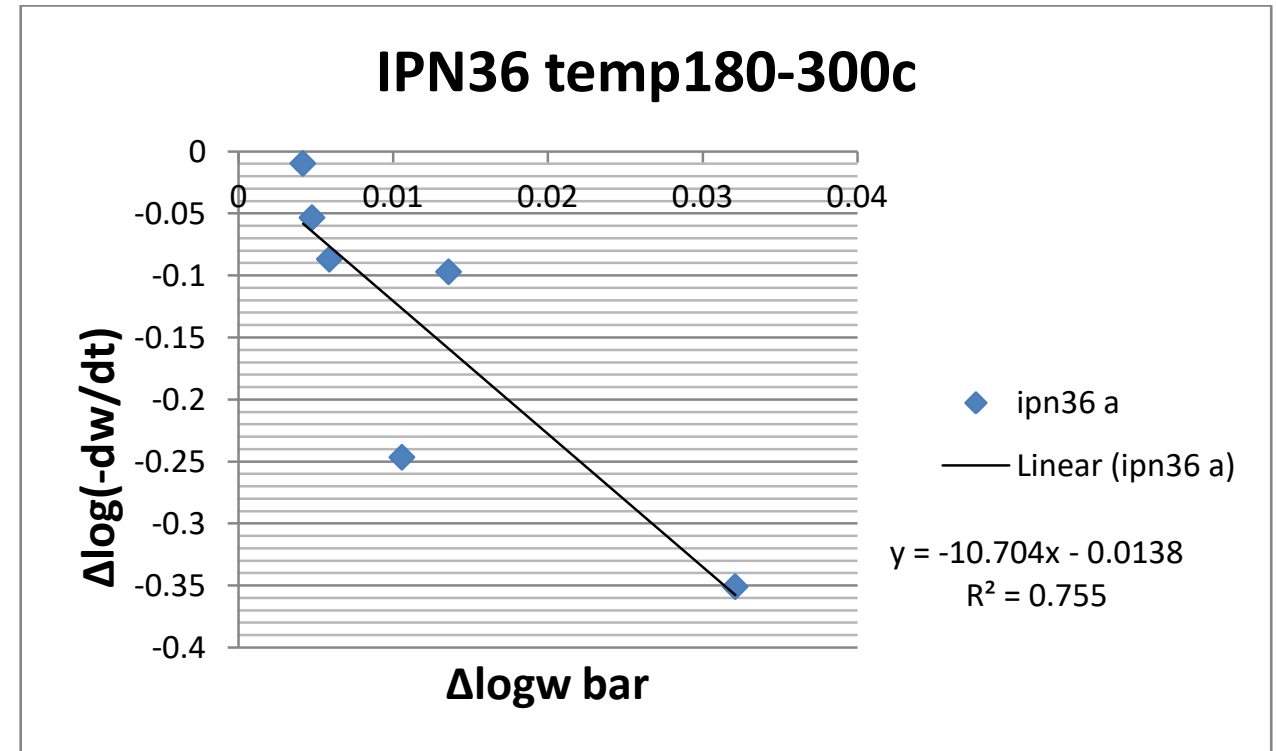

Fig 3g -Freeman-Anderson Plot of IPN36

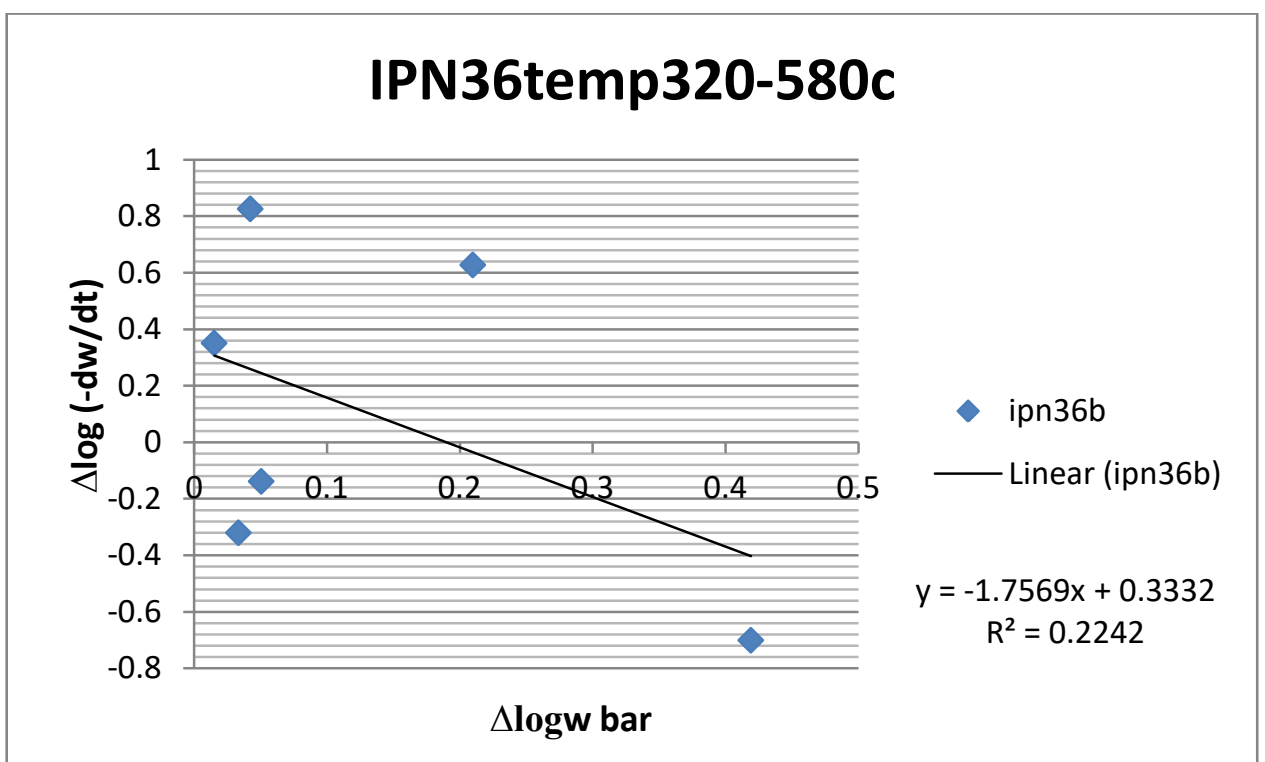

Fig 3h -Freeman-Anderson Plot of IPN 36

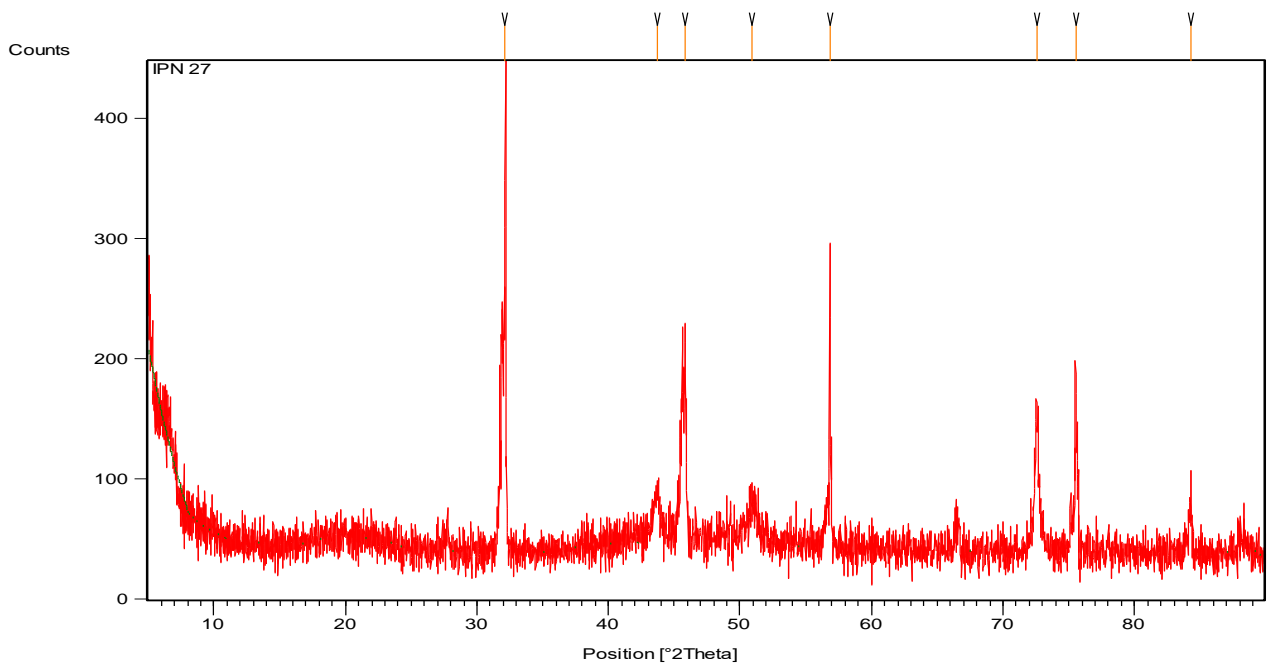

Fig 4a-WAXRD OF IPN 27 
Peak List: (Bookmark 3)

\begin{tabular}{|r|r|r|r|r|}
\hline Pos. [ ${ }^{\circ}$ Th.] & Height [cts] & FWHM [ ${ }^{\circ}$ 2Th.] & d-spacing [A] & \multicolumn{1}{c|}{ Rel. Int. [\%] } \\
\hline 32.1472 & 296.40 & 0.1440 & 2.78215 & 100.00 \\
\hline 43.6773 & 39.96 & 0.5760 & 2.07073 & 13.48 \\
\hline 45.8599 & 152.13 & 0.1920 & 1.97713 & 51.33 \\
\hline 50.9136 & 31.27 & 1.1520 & 1.79210 & 10.55 \\
\hline 56.8643 & 145.80 & 0.1920 & 1.61787 & 49.19 \\
\hline 72.5808 & 112.13 & 0.2880 & 1.30145 & 37.83 \\
\hline 75.5410 & 139.77 & 0.1920 & 1.25763 & 47.15 \\
\hline 84.2679 & 39.83 & 0.2880 & 1.14822 & 13.44 \\
\hline
\end{tabular}

Table 4a

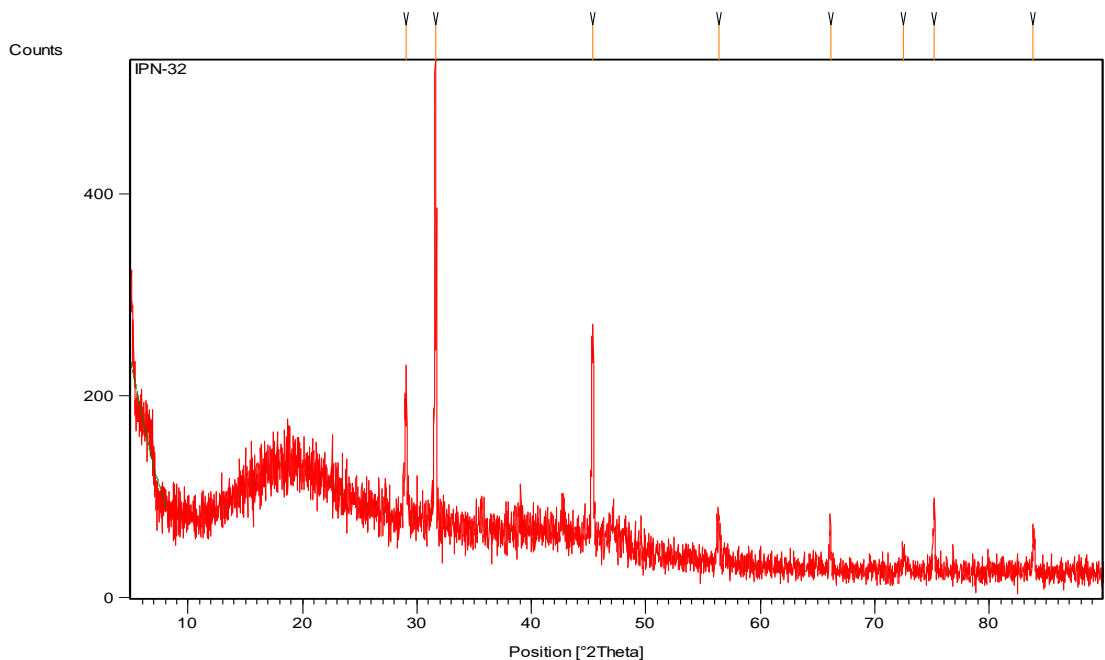

Fig 4b-WAXRD OF IPN 32

Peak List: (Bookmark 3)

\begin{tabular}{|c|c|c|c|c|}
\hline Pos. [ $\left.{ }^{\circ} 2 \mathrm{Th}.\right]$ & Height [cts] & FWHM [ $\left.{ }^{\circ} 2 \mathrm{Th}.\right]$ & d-spacing $[\AA]$ & Rel. Int. [\%] \\
\hline 29.0285 & 115.74 & 0.1920 & 3.07356 & 34.09 \\
\hline 31.6297 & 339.47 & 0.1920 & 2.82648 & 100.00 \\
\hline 45.3866 & 207.38 & 0.1920 & 1.99664 & 61.09 \\
\hline 56.3433 & 40.44 & 0.2880 & 1.63159 & 11.91 \\
\hline 66.1179 & 43.32 & 0.1920 & 1.41209 & 12.76 \\
\hline 72.5183 & 11.55 & 1.1520 & 1.30242 & 3.40 \\
\hline 75.1681 & 65.91 & 0.1920 & 1.26294 & 19.42 \\
\hline 83.8281 & 26.47 & 0.5760 & 1.15312 & 7.80 \\
\hline
\end{tabular}

Table 4b

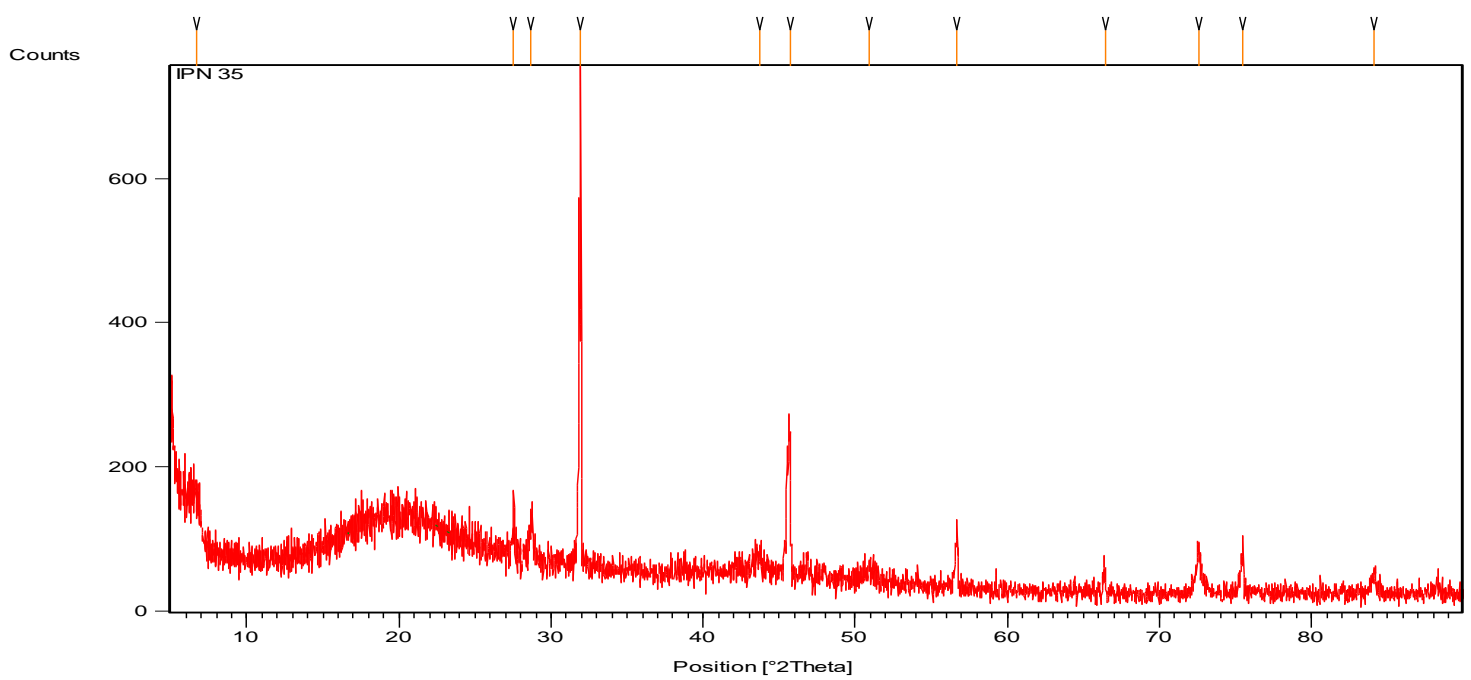

Fig 4c-WAXRD OF IPN 35 
Peak List: (Bookmark 3)

\begin{tabular}{|c|c|c|c|c|}
\hline Pos. [ ${ }^{\circ} 2$ Th.] & Height [cts] & FWHM [ $\left.{ }^{\circ} 2 \mathrm{Th}.\right]$ & d-spacing $[\AA]$ & Rel. Int. [\%] \\
\hline 6.6666 & 90.67 & 0.7680 & 13.24802 & 19.91 \\
\hline 27.5257 & 37.27 & 0.2880 & 3.23786 & 8.18 \\
\hline 28.6765 & 56.19 & 0.2880 & 3.11048 & 12.34 \\
\hline 31.9249 & 455.32 & 0.2400 & 2.80101 & 100.00 \\
\hline 43.7147 & 23.36 & 1.1520 & 2.06904 & 5.13 \\
\hline 45.7059 & 198.80 & 0.1440 & 1.98343 & 43.66 \\
\hline 50.8830 & 16.76 & 1.1520 & 1.79311 & 3.68 \\
\hline 56.7027 & 80.56 & 0.1920 & 1.62210 & 17.69 \\
\hline 66.4155 & 41.35 & 0.2880 & 1.40648 & 9.08 \\
\hline 72.5588 & 64.51 & 0.2880 & 1.30179 & 14.17 \\
\hline 75.4177 & 52.92 & 0.2880 & 1.25938 & 11.62 \\
\hline 84.1301 & 32.61 & 0.2880 & 1.14974 & 7.16 \\
\hline
\end{tabular}

Table 4c

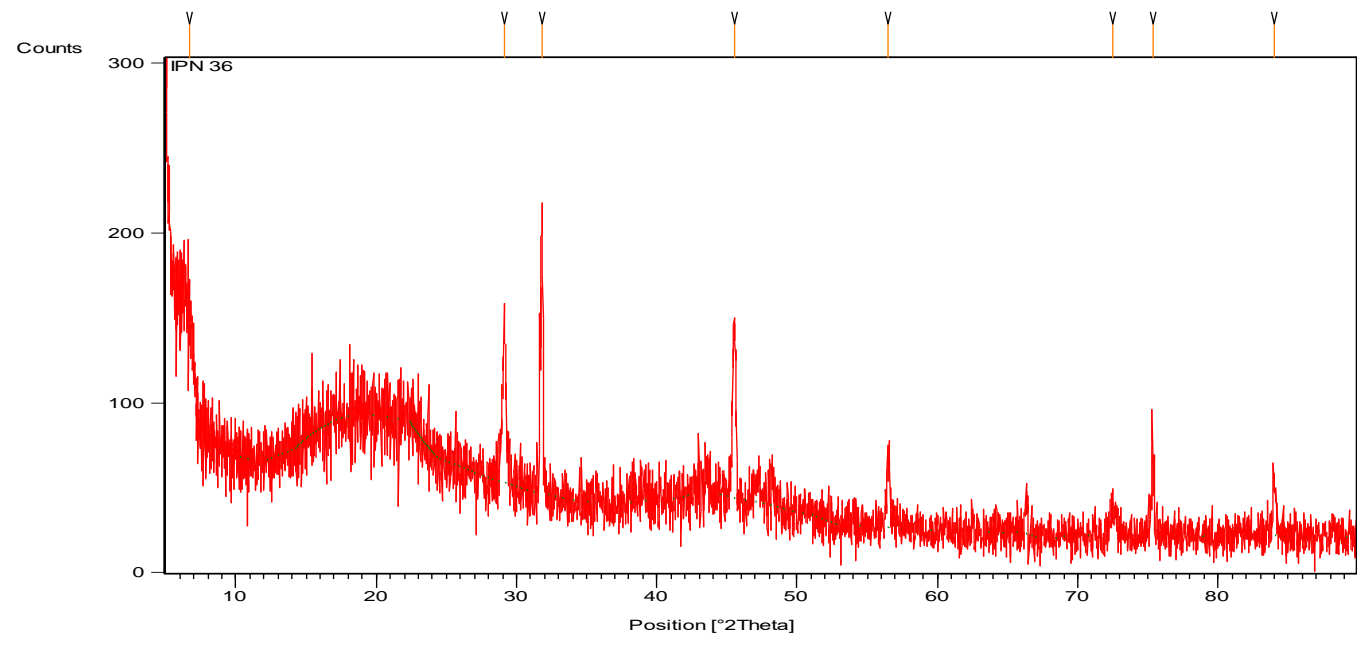

Fig 4d -WAXRD OF IPN 36

\begin{tabular}{|r|r|r|r|r|}
\hline Pos. [ ${ }^{\circ}$ Th.] & Height [cts] & FWHM [ ${ }^{\circ}$ 2Th.] & d-spacing [̊] & Rel. Int. [\%] \\
\hline 6.7354 & 82.44 & 0.9600 & 13.11282 & 51.00 \\
\hline 29.1594 & 86.73 & 0.1920 & 3.06007 & 53.66 \\
\hline 31.8412 & 161.64 & 0.2880 & 2.80819 & 100.00 \\
\hline 45.5602 & 98.92 & 0.3360 & 1.98943 & 61.20 \\
\hline 56.4868 & 39.27 & 0.2880 & 1.62779 & 24.29 \\
\hline 72.5015 & 14.90 & 0.5760 & 1.30268 & 9.22 \\
\hline 75.4015 & 35.32 & 0.2880 & 1.25961 & 21.85 \\
\hline 84.0270 & 29.05 & 0.2880 & 15089 & 17.98 \\
\hline
\end{tabular}

Table 4d

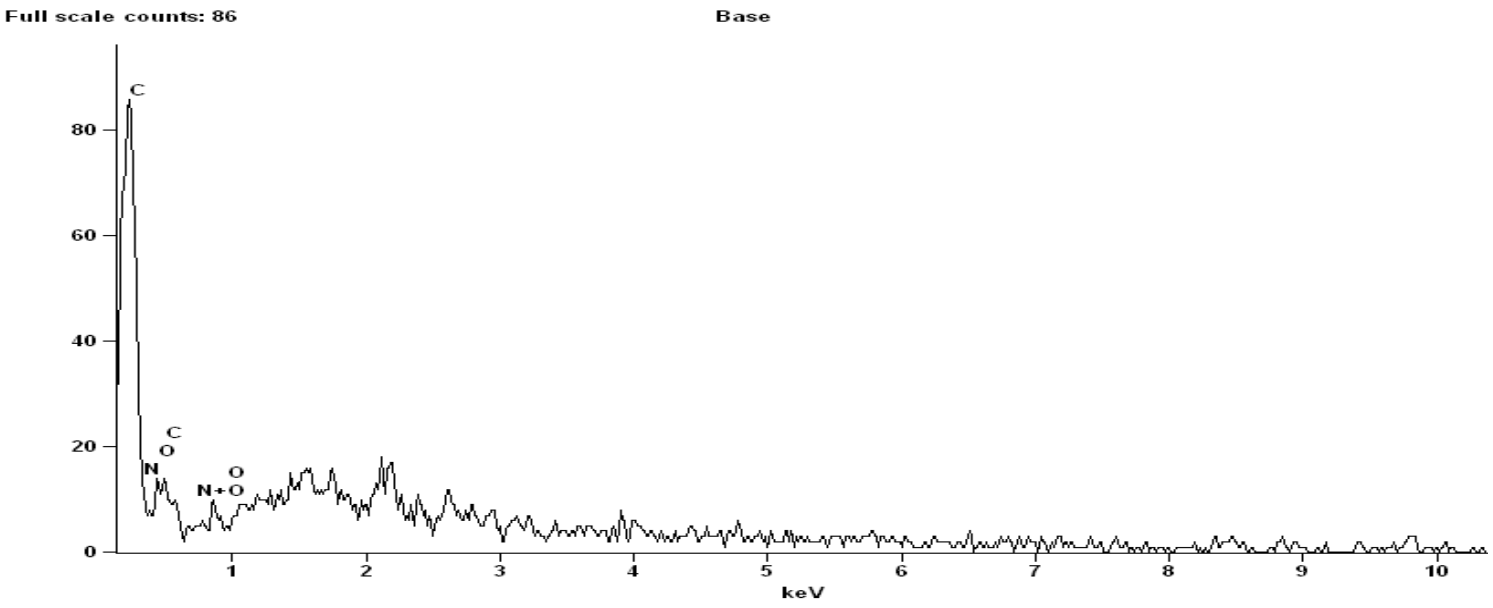

Fig 5a-IPN 27 


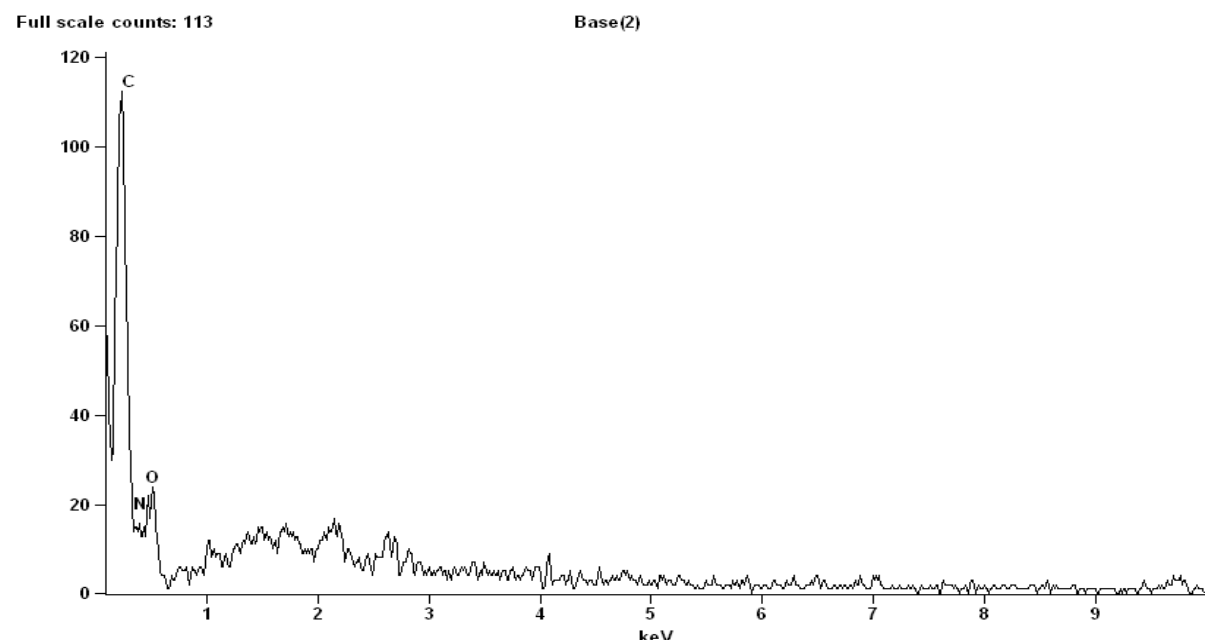

Fig $5 \mathbf{b}$ - IPN 32

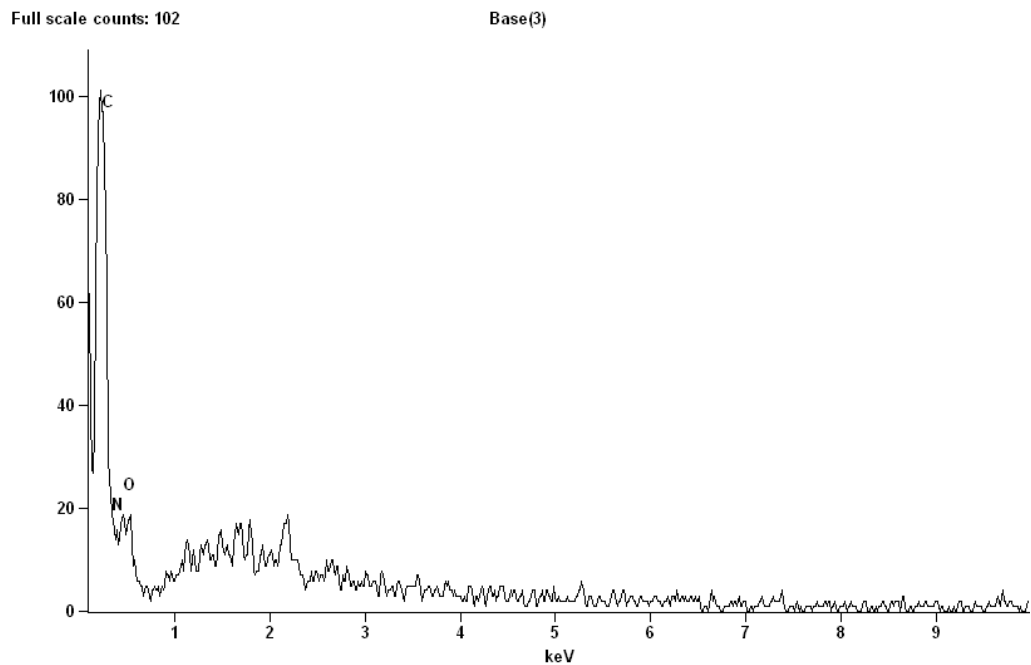

Fig 5c - IPN 35

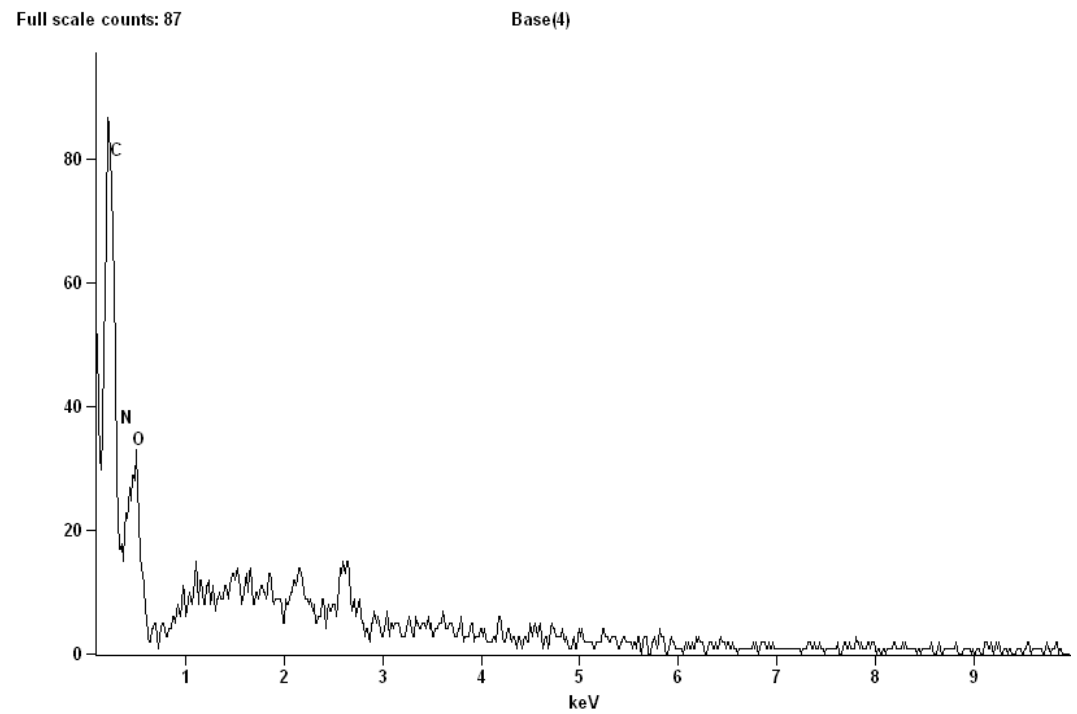

Fig 5d - IPN 36 


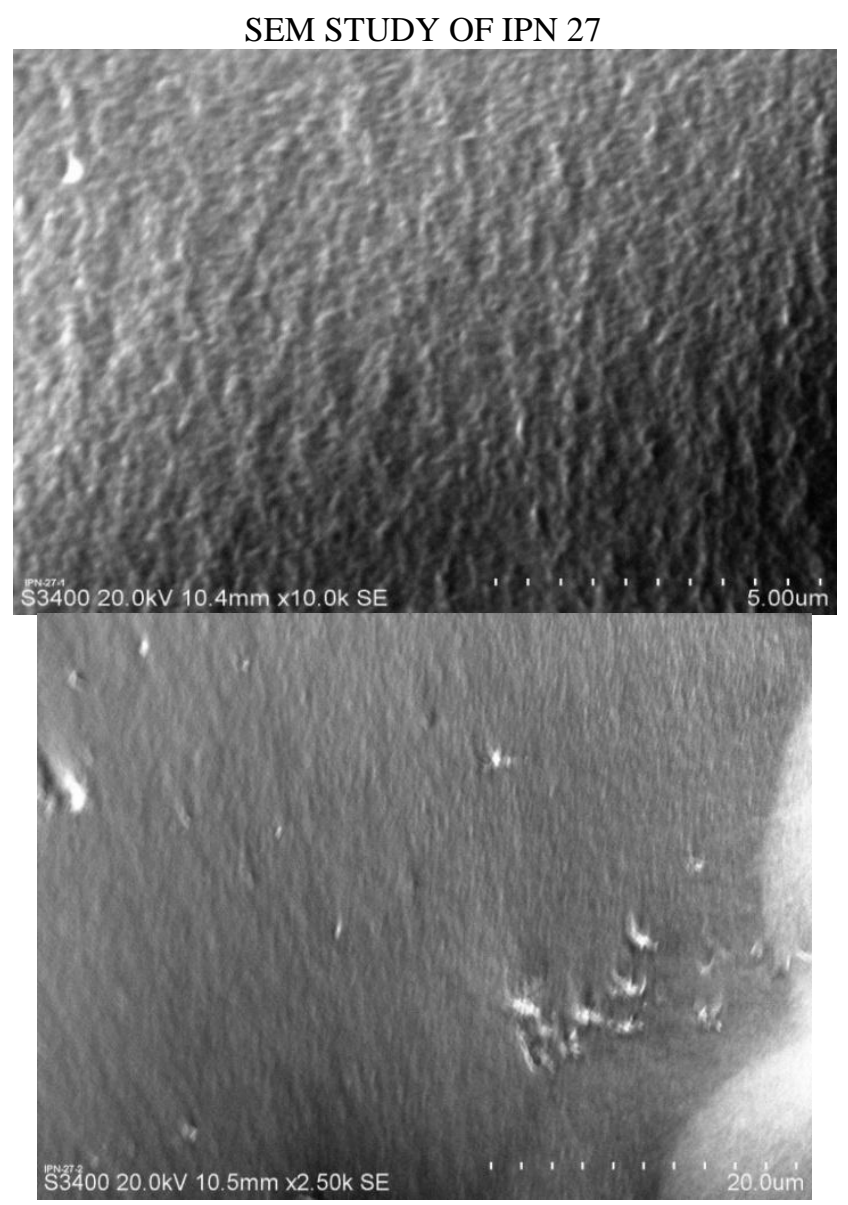

Fig 6a Fig 6b

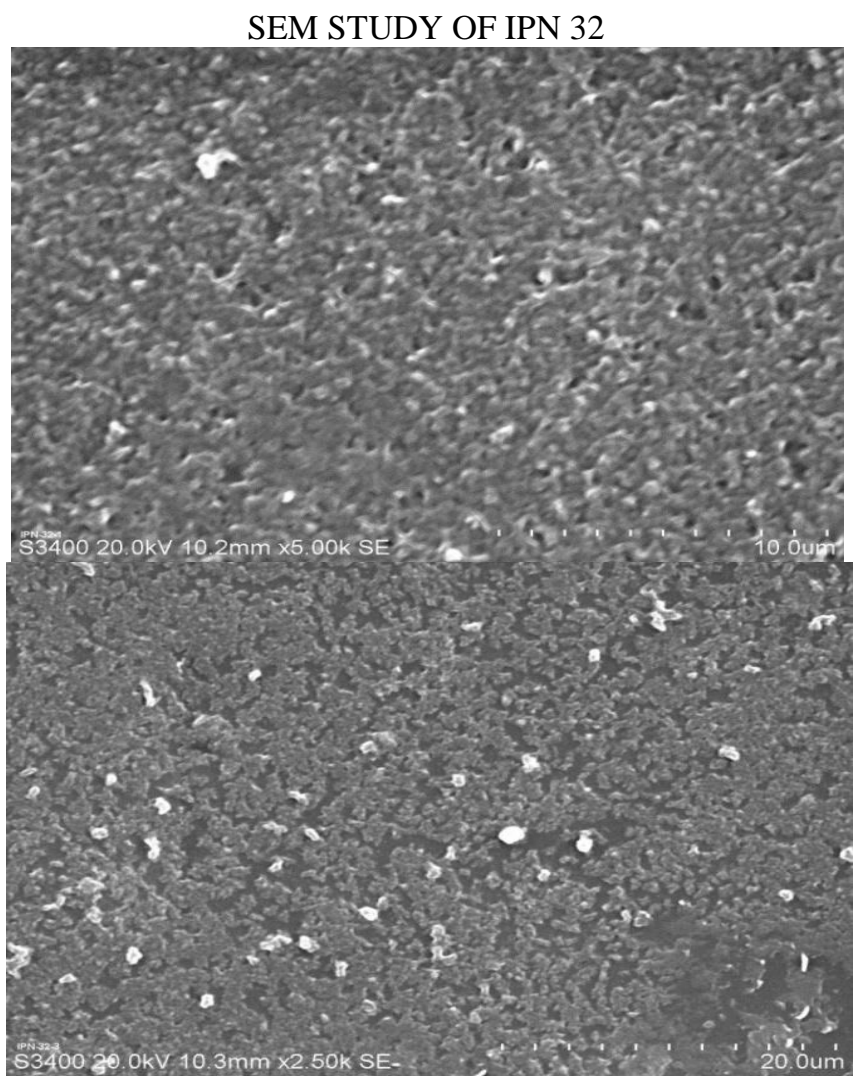

Fig 6c Fig 6d 


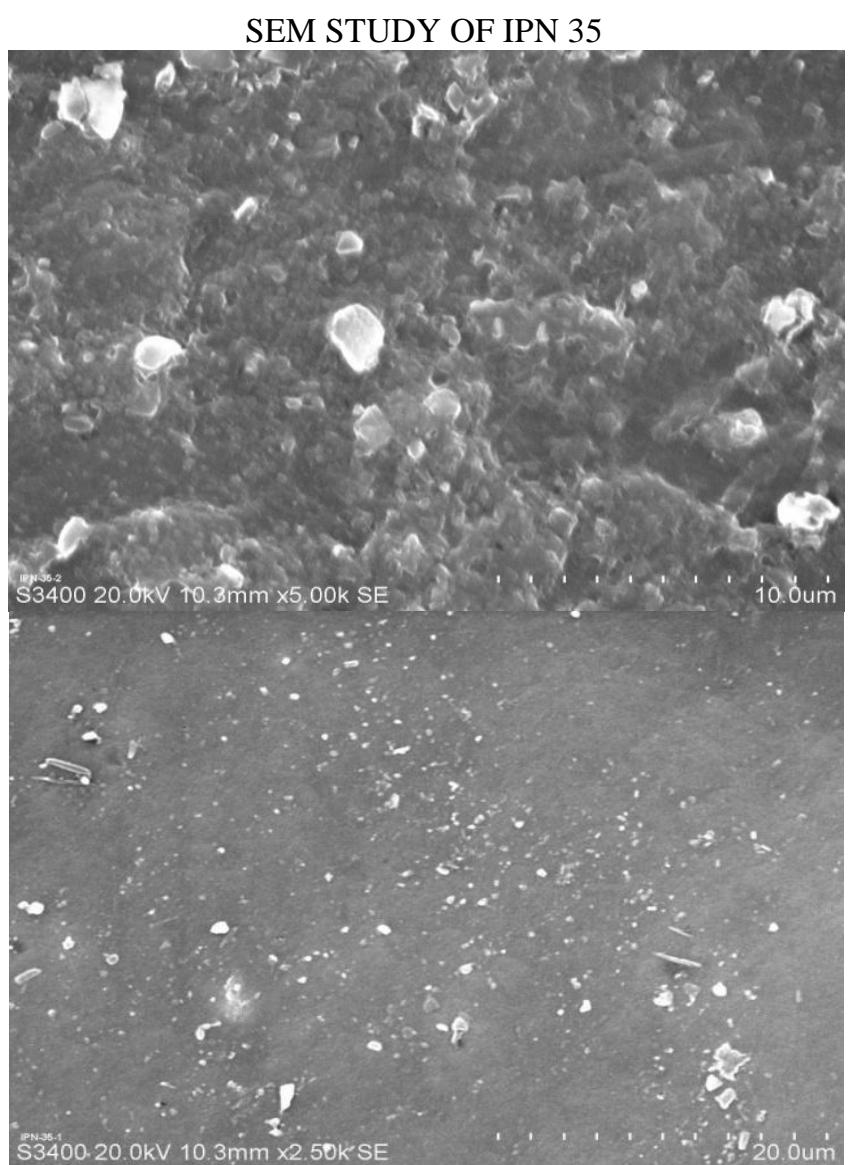

Fig 6e Fig $6 \mathrm{f}$

SEM STUDY OF IPN 36
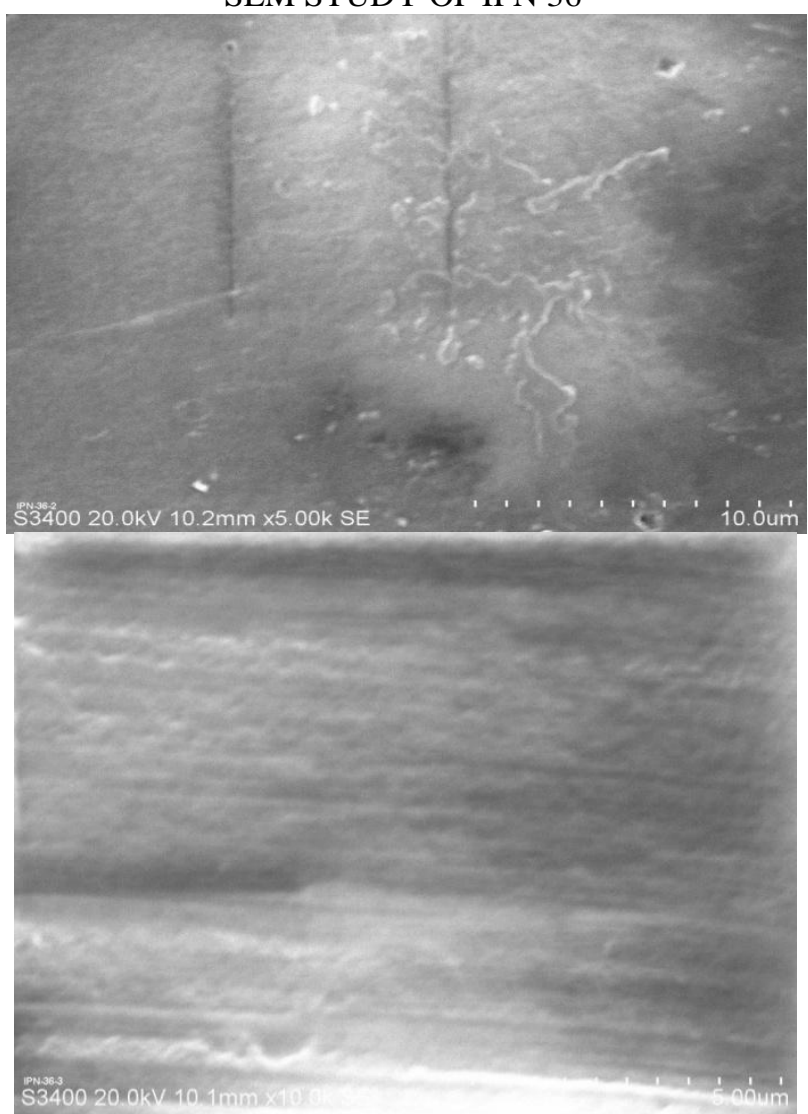

Fig $6 \mathrm{~g} \quad$ Fig $6 \mathrm{~h}$ 
Table 1. FEED COMPOSITION DATA

\begin{tabular}{|c|c|c|c|c|}
\hline Sl. No. & Sample code & Composition & NCO/OH & PU/CBD \\
\hline 1 & IPN 27 & $\begin{array}{c}\text { PS+DPMDI+CD of 3- } \\
\text { amino benzoic acid }\end{array}$ & 2.0 & $0.50 / 0.50$ \\
\hline 2 & IPN 32 & $\begin{array}{c}\text { PS+DPMDI+CD of 4- } \\
\text { amino benzoic acid }\end{array}$ & 1.6 & $0.35 / 0.65$ \\
\hline 3 & IPN 35 & $\begin{array}{c}\text { PS+DPMDI+CD of 4- } \\
\text { amino benzoic acid }\end{array}$ & 2.0 & $0.35 / 0.65$ \\
\hline 4 & IPN 36 & $\begin{array}{c}\text { PS+DPMDI of 4-amino } \\
\text { benzoic acid }\end{array}$ & 2.0 & $0.50 / 0.50$ \\
\hline
\end{tabular}

Table-2 DSC PARAMETERS

\begin{tabular}{|l|l|l|l|l|l|l|l|l|}
\hline S1 No. & \multirow{2}{*}{$\begin{array}{l}\text { Sample } \\
\text { code }\end{array}$} & $\begin{array}{l}\text { Composition } \\
\text { of IPNs }\end{array}$ & $\begin{array}{l}\text { PU/CBD } \\
\text { Weight } \\
\text { ratio }\end{array}$ & $\begin{array}{l}\text { NCO/ } \\
\mathrm{OH}\end{array}$ & $\begin{array}{l}\text { Tg in } \\
{ }^{0} \mathrm{C}\end{array}$ & $\begin{array}{l}\text { Tc in } \\
{ }^{0} \mathrm{C}\end{array}$ & $\begin{array}{l}\text { Tm in } \\
{ }^{0} \mathrm{C}\end{array}$ \\
\cline { 3 - 9 } & $\mathrm{IPN}_{27}$ & $\begin{array}{l}\text { GSO+ } \\
\text { DPMDI }\end{array}$ & $\begin{array}{l}\text { C-amino } \\
\text { Benzoic acid }\end{array}$ & $50: 50$ & 2.0 & 175.5 & 307.02 & $\mathbf{4 7 2 . 3}$ \\
\hline 2 & IPN $_{32}$ & $\begin{array}{l}\text { GSO+ } \\
\text { DPMDI }\end{array}$ & $\begin{array}{l}\text { 4-amino } \\
\text { Benzoic acid }\end{array}$ & $35: 65$ & 1.6 & 137.2 & 420.1 & $\mathbf{4 2 0 . 6}$ \\
\hline 3 & IPN $_{35}$ & $\begin{array}{l}\text { GSO+ } \\
\text { DPMDI }\end{array}$ & $\begin{array}{l}\text { 4-amino } \\
\text { Benzoic acid }\end{array}$ & $35: 65$ & 2.0 & 177.2 & 294.8 & $\mathbf{4 6 1 . 6 5}$ \\
\hline 4 & IPN $_{36}$ & $\begin{array}{l}\text { GSO+ } \\
\text { DPMDI }\end{array}$ & $\begin{array}{l}\text { 4-amino } \\
\text { Benzoic acid }\end{array}$ & $50: 50$ & 2.0 & 162.5 & $\begin{array}{l}294.82 \\
416.6\end{array}$ & $\mathbf{4 6 1 . 7}$ \\
\hline
\end{tabular}

$\mathrm{Tg}=$ glass transition temperature, $\mathrm{Tc}=$ curieing temperature, $\mathrm{Tm}=$ Melting point

Table-3a Percentage Of Ipn Samples Left After Thermal Degradation

\begin{tabular}{|c|c|c|c|c|c|c|c|c|c|}
\hline \multirow[t]{2}{*}{ S1 No. } & \multirow[t]{2}{*}{ Sample } & \multirow[t]{2}{*}{ Composition } & \multicolumn{7}{|c|}{ Range of temperature } \\
\hline & & & 100 & 200 & 300 & 400 & 500 & 600 & 700 \\
\hline 1 & $\mathrm{IPN}_{27}$ & $\begin{array}{l}\text { MEP of SO + } \\
\text { DPMDI + 3amino } \\
\text { Benzoic acid }\end{array}$ & 98.4 & 93 & 76.4 & 57.6 & 21.9 & 17.8 & 17.8 \\
\hline 2 & $\mathrm{IPN}_{32}$ & $\begin{array}{l}\text { MEP of SO + } \\
\text { DPMDI + 3amino } \\
\text { Benzoic acid }\end{array}$ & 94.8 & 82.6 & 60.7 & 39.4 & 1.3 & - & - \\
\hline 3 & $\mathrm{IPN}_{35}$ & $\begin{array}{l}\text { MEP of SO + } \\
\text { DPMDI + 3amino } \\
\text { Benzoic acid }\end{array}$ & 99.3 & 94.6 & 82.5 & 67.8 & 22.55 & 19.9 & 19.2 \\
\hline 4 & $\mathrm{IPN}_{36}$ & $\begin{array}{l}\text { MEP of SO + } \\
\text { DPMDI + 3amino } \\
\text { Benzoic acid }\end{array}$ & 98.7 & 94.4 & 81.8 & 65.1 & 16.3 & 13.6 & 12.9 \\
\hline
\end{tabular}

Table - 3b Kinetic parameters of different IPNs

\begin{tabular}{|l|l|l|r|r|}
\hline Sample Codes & Temperature Range & Slope or Order of reaction & Activation Energy & Intercept \\
\hline \multirow{3}{*}{ IPN27 } & $140-300$ & 0.2134 & 191.149 & -0.1 \\
\cline { 2 - 6 } & $320-660$ & -1.8942 & -691.19478 & 0.3616 \\
\hline \multirow{2}{*}{ IPN32 } & $180-300$ & -3.996 & -43.581972 & 0.0228 \\
\cline { 2 - 6 } & $300-440$ & -1.0014 & -34.789118 & 0.0182 \\
\hline \multirow{2}{*}{ IPN 35 } & $180-300$ & -10.395 & -803.78155 & -0.0032 \\
\cline { 2 - 6 } & $320-580$ & -2.7442 & 26.378562 & 0.4205 \\
\hline IPN36 & $180-300$ & -10.704 & -636.90847 & -0.0138 \\
\cline { 2 - 6 } & $320-580$ & -1.7569 & & 0.3332 \\
\hline
\end{tabular}

Table-4 PERCENTAGE OF DIFFERENT ELEMENTS IN THE IPNS QUANTITATIVE RESULTS BASE

\begin{tabular}{|c|c|c|c|c|c|c|}
\hline $\boldsymbol{C} \boldsymbol{K}$ & 549 & $+/-$ & 40 & 81.82 & 85.70 & $\mathrm{C}$ \\
\hline $\boldsymbol{N} \boldsymbol{K}$ & 0 & $+/-$ & 11 & 0.00 & 0.00 & $\mathrm{~N}$ \\
\hline $\boldsymbol{O} \boldsymbol{K}$ & 74 & $+/-$ & 15 & 18.18 & 14.30 & $\mathrm{O}$ \\
\hline Total & & & 100.00 & 100.00 & \\
\hline
\end{tabular}

BASE 1 TABLE-4a

\begin{tabular}{|c|c|c|c|c|c|}
\hline$C K$ & 681 & $+/-\quad 45$ & 77.61 & 82.19 & $\mathrm{C}$ \\
\hline$N K$ & 0 & $+/-\quad 14$ & 0.00 & 0.00 & $\bar{N}$ \\
\hline$O K$ & 133 & $+/-\quad 16$ & 22.39 & 17.81 & $\mathrm{O}$ \\
\hline Total & & & 100.00 & 100.00 & \\
\hline
\end{tabular}

BASE 2 TABLE-4b

\begin{tabular}{|c|c|c|c|c|c|}
\hline$C K$ & 649 & $+/-\quad 45$ & 81.52 & 85.46 & $\mathrm{C}$ \\
\hline$N K$ & 0 & $+/-$ & 0.00 & 0.00 & $\mathrm{~N}$ \\
\hline$O K$ & 91 & $+/-\quad 17$ & 18.48 & 14.54 & $\mathrm{O}$ \\
\hline Total & & & 100.00 & 100.00 & \\
\hline
\end{tabular}

BASE-3 TABLE-4c 
Comparison of Thermal Degradation, WAXRD Studies and SEM of Renewable Resources Based

\begin{tabular}{|c|c|c|c|c|c|}
\hline $\boldsymbol{C} \boldsymbol{K}$ & 469 & $+/-\quad 58$ & 55.45 & 61.29 & $\mathrm{C}$ \\
\hline $\boldsymbol{N} \boldsymbol{K}$ & 27 & $+/-\quad 40$ & 14.77 & $\mathrm{~N}$ & \\
\hline $\boldsymbol{O} \boldsymbol{K}$ & 201 & $+/-\quad 38$ & 29.77 & 24.71 & \\
\hline $\boldsymbol{T o t a l}$ & & & 100.00 & 100.00 & \\
\hline
\end{tabular}

BASE 4 TABLE-4d

\begin{tabular}{|c|c|c|c|c|c|}
\hline$C K$ & 442 & $+/-\quad 54$ & 56.50 & 61.91 & $\mathrm{C}$ \\
\hline$N K$ & 32 & $+/-$ & 19.81 & 18.61 & $\mathrm{~N}$ \\
\hline Total & & & 100.00 & 100.00 & \\
\hline
\end{tabular}

BASE 5 TABLE-4e

\begin{tabular}{|c|c|c|c|c|c|}
\hline$C K$ & 398 & $+/-\quad 48$ & 54.75 & 60.63 & $\mathrm{C}$ \\
\hline$N K$ & 24 & $+/-$ & 14.91 & 14.16 & $\mathrm{~N}$ \\
\hline$O K$ & 179 & $+/-$ & 30.33 & 25.22 & $\mathrm{O}$ \\
\hline Total & & & 100.00 & 100.00 & \\
\hline
\end{tabular}

BASE 7 TABLE-4f

\begin{tabular}{|c|c|c|c|c|c|}
\hline $\boldsymbol{C} \boldsymbol{K}$ & 375 & $+/-45$ & 60.22 & 65.69 & $\mathrm{C}$ \\
\hline $\boldsymbol{N} \boldsymbol{K}$ & 18 & $+/-\quad 34$ & 14.90 & 13.94 & $\mathrm{~N}$ \\
\hline $\boldsymbol{O} \boldsymbol{K}$ & 110 & $+/-\quad 21$ & 24.88 & 20.37 & $\mathrm{O}$ \\
\hline $\boldsymbol{T o t a l}$ & & & 100.00 & 100.00 & \\
\hline
\end{tabular}

BASE 8 TABLE-4g

\begin{tabular}{|c|c|c|c|c|c|}
\hline$C K$ & 288 & $+/-\quad 37$ & 69.53 & 75.25 & $\mathrm{C}$ \\
\hline$N K$ & 0 & $+/-\quad 11$ & 0.00 & 0.00 & $\mathrm{~N}$ \\
\hline$O K$ & 105 & $+/-\quad 14$ & 30.47 & 24.75 & $\mathrm{O}$ \\
\hline Total & & & 100.00 & 100.00 & \\
\hline
\end{tabular}

BASE 14 TABLE-4h

\begin{tabular}{|c|c|c|c|c|c|}
\hline$C K$ & 344 & $+/-\quad 45$ & 69.60 & 75.02 & $\mathrm{C}$ \\
\hline$N \mathrm{~K}$ & 3 & $+/-$ & 3.36 & 3.10 & $\mathrm{~N}$ \\
\hline$O K$ & 101 & $+/-$ & 27.04 & 21.88 & $\mathrm{O}$ \\
\hline Total & & & 100.00 & 100.00 & \\
\hline
\end{tabular}

BASE 15 TABLE-4i

\begin{tabular}{|c|c|c|c|c|c|}
\hline$C K$ & 405 & $+1-\quad 44$ & 56.69 & 62.22 & $\mathrm{C}$ \\
\hline$N K$ & 27 & $+/-\quad 34$ & 17.83 & 16.78 & $\mathrm{~N}$ \\
\hline$O K$ & 131 & $+/-\quad 21$ & 25.48 & 21.00 & $\mathrm{O}$ \\
\hline Total & & & 100.00 & 100.00 & \\
\hline
\end{tabular}

BASE 17 TABLE-4j

\begin{tabular}{|c|c|c|c|c|c|}
\hline $\boldsymbol{C} \boldsymbol{K}$ & 229 & $+/-26$ & 80.63 & 84.72 & $\mathrm{C}$ \\
\hline $\boldsymbol{N} \boldsymbol{K}$ & 0 & 0 & 0.00 & 0.00 & $\mathrm{~N}$ \\
\hline $\boldsymbol{O} \boldsymbol{K}$ & 35 & 35 & 19.37 & 15.28 & $\mathrm{O}$ \\
\hline Total & & & 100.00 & 100.00 & \\
\hline
\end{tabular}

BASE 19 TABLE-4k

Table-5 WAXRD STUDY

\begin{tabular}{|r|r|r|r|r|}
\hline Pos. [ ${ }^{\circ}$ Th.] & Height [cts] & FWHM [ ${ }^{\circ}$ 2Th.] & d-spacing [̊] & \multicolumn{1}{|c|}{ Rel. Int. [\%] } \\
\hline 6.6666 & 90.67 & 0.7680 & 13.24802 & 19.91 \\
\hline 27.5257 & 37.27 & 0.2880 & 3.23786 & 8.18 \\
\hline 28.6765 & 56.19 & 0.2880 & 3.11048 & 12.34 \\
\hline 31.9249 & 455.32 & 0.2400 & 2.80101 & 5.13 \\
\hline 43.7147 & 23.36 & 1.1520 & 2.06904 & 43.66 \\
\hline 45.7059 & 198.80 & 0.1440 & 1.98343 & 3.68 \\
\hline 50.8830 & 16.76 & 1.1520 & 1.79311 & 17.69 \\
\hline 56.7027 & 80.56 & 0.1920 & 1.62210 & 9.08 \\
\hline 66.4155 & 41.35 & 0.2880 & 1.40648 & 14.17 \\
\hline 72.5588 & 64.51 & 0.2880 & 1.30179 & 11.62 \\
\hline 75.4177 & 52.92 & 0.2880 & 1.25938 & 7.16 \\
\hline 84.1301 & 32.61 & 0.2880 & 1.14974 & \\
\hline
\end{tabular}


Comparison of Thermal Degradation, WAXRD Studies and SEM of Renewable Resources Based

\begin{tabular}{|r|r|r|r|r|}
\hline Pos. [ ${ }^{\circ}$ Th.] & Height [cts] & FWHM [ ${ }^{\circ}$ 2Th.] & d-spacing [̊] & \multicolumn{1}{c|}{ Rel. Int. [\%] } \\
\hline 6.7354 & 82.44 & 0.9600 & 13.11282 & 51.00 \\
\hline 29.1594 & 86.73 & 0.1920 & 3.06007 & 53.66 \\
\hline 31.8412 & 161.64 & 0.2880 & 2.80819 & 100.00 \\
\hline 45.5602 & 98.92 & 0.3360 & 1.98943 & 61.20 \\
\hline 56.4868 & 39.27 & 0.2880 & 1.62779 & 24.29 \\
\hline 72.5015 & 14.90 & 0.5760 & 1.30268 & 9.22 \\
\hline 75.4015 & 35.32 & 0.2880 & 1.25961 & 21.85 \\
\hline 84.0270 & 29.05 & 0.2880 & 1.15089 & 17.98 \\
\hline
\end{tabular}

TABLE-6 Decomposition By Bacteria And Virus

\begin{tabular}{|c|c|c|c|c|c|c|}
\hline Sl. No & Sample Code & Initial mass & $\begin{array}{c}\text { Mass after 15 } \\
\text { days }\end{array}$ & $\begin{array}{c}\text { Mass after 30 } \\
\text { days }\end{array}$ & $\begin{array}{c}\text { Mass after 45 } \\
\text { days }\end{array}$ & $\begin{array}{c}\text { Mass after 60 } \\
\text { days }\end{array}$ \\
\hline 1 & IPN27 & 10.42 & 10.36 & 10.23 & 10.11 & \\
\hline 2 & IPN32 & 9.97 & 9.86 & 9.57 & 9.43 & 10.01 \\
\hline 3 & IPN35 & 9.62 & 9.42 & 9.4 & 9.32 & \\
\hline 4 & IPN36 & 10.31 & 10.23 & 10.2 & 9.9 & 9.29 \\
\hline
\end{tabular}

